Review Article

\title{
Influence of Ground Temperature on Shotcrete-to-Rock Adhesion in Tunnels
}

\author{
Limin Duan $(\mathbb{D}$, Yuanhang Zhang, and Jinxing Lai $(\mathbb{D}$ \\ School of Highway, Chang'an University, Xi'an 710064, China \\ Correspondence should be addressed to Jinxing Lai; laijinxing@chd.edu.cn
}

Received 1 February 2019; Revised 8 April 2019; Accepted 2 May 2019; Published 4 June 2019

Academic Editor: Charles C. Sorrell

Copyright ( 2019 Limin Duan et al. This is an open access article distributed under the Creative Commons Attribution License, which permits unrestricted use, distribution, and reproduction in any medium, provided the original work is properly cited.

\begin{abstract}
Long and deep tunnels are increasingly designed and built worldwide, often in severe geothermal environments characterized by high temperature in the rocks. This issue cannot be ignored because high temperature definitely affects the strength of the adhesion between the concrete and the surrounding rocks, whatever the lining cast in place, segmental or sprayed using shotcrete. The causes of geothermal heat and the effect of the temperature on tunnel linings during and after their construction are recalled and discussed in this paper. Both temperature and humidity are shown to be the most relevant factors affecting adhesion strength, whose loss is related to the microdamage in the shotcrete layers closest to the rock. Possible ways to improve adhesion strength and to minimize the high-temperature detrimental effect are also presented and discussed.
\end{abstract}

\section{Introduction}

With the development of global tunnel engineering and water preservation and hydropower projects, the method of shotcreting has been widely applied to deep tunnels and diversion power tunnels as the main support method. Concrete has the characteristics of high compressive strength, high early strength, good durability, and wide range of strength grades. Shotcrete can not only prevent oxidative deterioration of surrounding rock but also strengthen the support ability of the tunnel lining structure and greatly improve tunnel stability $[1,2]$. Concrete is the most widely used and largest building material in civil engineering. Its engineering experience shows that the performance of concrete often plays a decisive role in engineering construction.

However, in the process of deep tunnel construction, it will often pass through high-temperature environment areas with frequent geothermal activities. For example, the maximum temperature of the diversion tunnel of Niangyong Hydropower Station in China reaches $78^{\circ} \mathrm{C}$, the maximum temperature of the Tecolote Road Tunnel in the United States of America reaches $47^{\circ} \mathrm{C}$, the maximum temperature of the Anfang Tunnel in Japan reaches $75^{\circ} \mathrm{C}$, and so on.
Figure 1 shows the success of building a tunnel in highly geothermal environments all around the world. As a matter of fact, the direct contact of concrete with hot rock will cause concrete desiccation on the concrete, causing significant degrees of shrinkage, which will further lead to cracks in the shotcrete-surrounded rock contact surface. The highly geothermal environment will reduce the adhesion strength of shotcrete-to-rock and increase the risk to tunnel operation and its use [3-5].

Lately, many experts and scholars have investigated the mechanisms and the controlling factors of shotcrete-to-rock coupling. Pottler [6] and others believe that the shotcreterock coupling is dominated by the nonlinear material properties of the shotcrete over time and the time-dependent tunnel excavation process. Pottler et al. used the twodimensional finite element method to obtain an approximate solution that does not require a time step. Suits et al. [7] extensively studied the shear properties of concrete or cement grouting with weakly weathered rock contact surfaces under constant normal stiffness. The rock is an artificial siltstone called John Stone, and the contact surface consists of a series of regular triangular shapes and irregular shapes based on analytical geometry theory. Bae et al. [8] obtained the tensile strength, cohesion, friction angle, shear stiffness, 


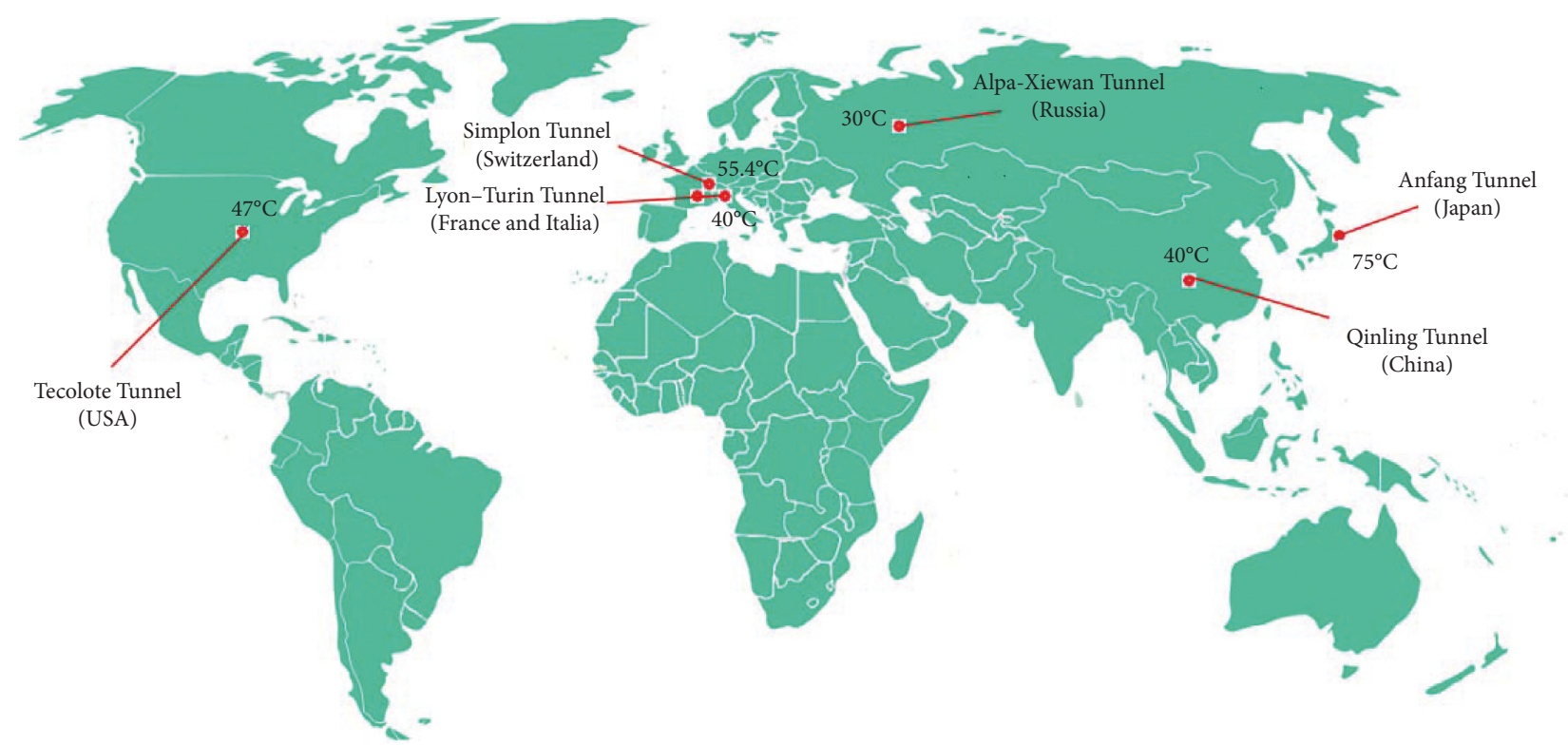

Figure 1: Geothermal values of tunnels in some countries around the world.

and normal stiffness of the joints of shotcrete-surrounded rock at different ages through the indoor direct shear test. Yilmaz [9] introduced a test method for testing the shear strength of thin-layer shotcrete and rock contact surfaces invented by the Rock Mechanics Laboratory of Kingsoft University in South Africa. Son [10] used the bulk discrete element program to analyse the sensitivity of shotcrete-rock coupling to some factors, including contact surface roughness, rock strength and Young's modulus, tunnel excavation disturbance or the size of the surrounding rock, the mechanical properties of the contact surface, the thickness of the shotcrete, etc. Liu [11] and others started from the research of shotcrete raw materials. They simulated the high-temperature and high-humidity environment in which the shotcrete was actually placed. The test block was cured and tested, and the material formula of the shotcrete was finally determined. Wang et al. [12] conducted a series of tests on the concrete lining construction technology of plateau geothermal tunnels to test the performance indexes of initial support shotcrete and secondary lining high performance concrete in a high-temperature environment. They proposed that the addition of high-temperature stabilizer in concrete is an effective measure to resolve the technical problems of concrete lining construction in highly geothermal environments $[13,14]$.

\section{Causes and Effects of Terrestrial Heat}

The data show that humans have been using geothermal energy for a long time; however, the terrestrial heat in the tunnel during construction can cause high-temperature damage to the project, which will have a major negative impact on construction safety and project quality. The terrestrial heat in the construction environment not only worsens the working conditions of mechanical equipment but also increases the number of failures; it also seriously jeopardizes the health and safety of workers. Therefore, it is necessary to analyse the causes of high ground temperature in combination with actual engineering examples (Table 1) and improve the understanding of the high ground temperature environment, so as to better resolve the hazards $[15,16,19-22]$.

Through the abovementioned high-temperature disaster cases, it can be found that if the high ground temperature problem occurs in the tunnel project, the construction environment, building materials, machinery and equipment, and the operation of the tunnel after completion will be inevitably affected (Figure 2). Globally, the adverse effects of geothermal high temperature on tunnel construction can be summarized as the following aspects $[2,17,23-25]$ :

(1) The impact of high-temperature environment on construction: in high-temperature environments, the efficiency of the construction workers will be greatly reduced. At the same time, it will lead to deterioration of working conditions of mechanical equipment, reduce efficiency, and increase failure. The deterioration of the environment will not only increase the construction difficulty but also delay milestones, impact financially on over budget and can even increase project scope.

(2) The impact of high-temperature environment on the supporting structure: the high-temperature environment will affect the adhesion of shotcrete-to-rock of the tunnel; therefore, the concrete supporting structure make it more likely fail, and the temperature stress generated by the gradient distribution of the temperature field affects the stability of the concrete supporting structure.

(3) The impact of high-temperature environment on materials: in the highly geothermal environments, it is necessary to consider whether it is resistant to high 
TABLE 1: Disaster cases of tunnel construction worldwide in highly geothermal environments.

\begin{tabular}{|c|c|c|}
\hline Tunnel name & Project overview & Thermal damage \\
\hline China-Nepal railway tunnel & $\begin{array}{l}\text { The railway planning route runs through two } \\
\text { geothermal activity zones in the Yarluzangbu river } \\
\text { and the Yarluzangbu river valley. The hot springs } \\
\text { along the line are extremely frequent, with water } \\
\text { temperatures up to } 88^{\circ} \mathrm{C} \text {. A total of } 45 \text { tunnels are } \\
\text { planned across the line, with a total length of } \\
\text { approximately } 272 \mathrm{~km}\end{array}$ & $\begin{array}{l}\text { Deteriorating the construction work environment, } \\
\text { reducing labor productivity and threatening the } \\
\text { health and safety of workers. The additional } \\
\text { temperature stress generated by the high ground } \\
\text { temperature will cause initial tunnel support and } \\
\text { secondary lining cracking, which will affect } \\
\text { structural safety and durability }[15,16]\end{array}$ \\
\hline Anfang Tunnel in Japan & $\begin{array}{l}\text { During the construction of the tunnel, the tunnel } \\
\text { encounters severe hot water problems and high- } \\
\text { temperature area problems. The maximum } \\
\text { temperature of the hot water flowing out of the } \\
\text { tunnel can reach } 73^{\circ} \mathrm{C} \text {, and the temperature of } \\
\text { some rock mass exceeds } 50^{\circ} \mathrm{C} \text {. The volcanic gas } \\
\text { exists in the tunnel, which seriously affects the } \\
\text { tunnel working environment }\end{array}$ & $\begin{array}{l}\text { Due to the terrestrial heat, the temperature of the } \\
\text { rock mass is very high, and the concrete hydration } \\
\text { heat is not easily released, resulting in excessive } \\
\text { temperature difference between the exterior and } \\
\text { the interior of the concrete, and there may be } \\
\text { cracks, which seriously affect the adhesion between } \\
\text { the concrete and the surrounding rock [15] }\end{array}$ \\
\hline Tokaanu Tunnel in New Zealand & $\begin{array}{l}\text { New Zealand's Tokaanu hydropower station and } \\
\text { Tokaanu Tunnel were built in a high-temperature } \\
\text { site. Through years of borehole investigation, it was } \\
\text { found that there was a large amount of high- } \\
\text { temperature underground hot water (some } \\
\text { temperatures exceeding } 100^{\circ} \mathrm{C} \text { ), and the front of the } \\
\text { tunnel face was affected by geothermal energy. The } \\
\text { tunnel temperature measured in the pilot hole of } \\
\text { the tunnel wall is too high }\end{array}$ & $\begin{array}{l}\text { The high temperature seriously affects the safety of } \\
\text { the tunnel structure. Excessive rock temperature } \\
\text { will cause the concrete to deteriorate and crack; at } \\
\text { the same time, the high-temperature heat flow will } \\
\text { pose a threat to people's lives and property }[17,18]\end{array}$ \\
\hline
\end{tabular}

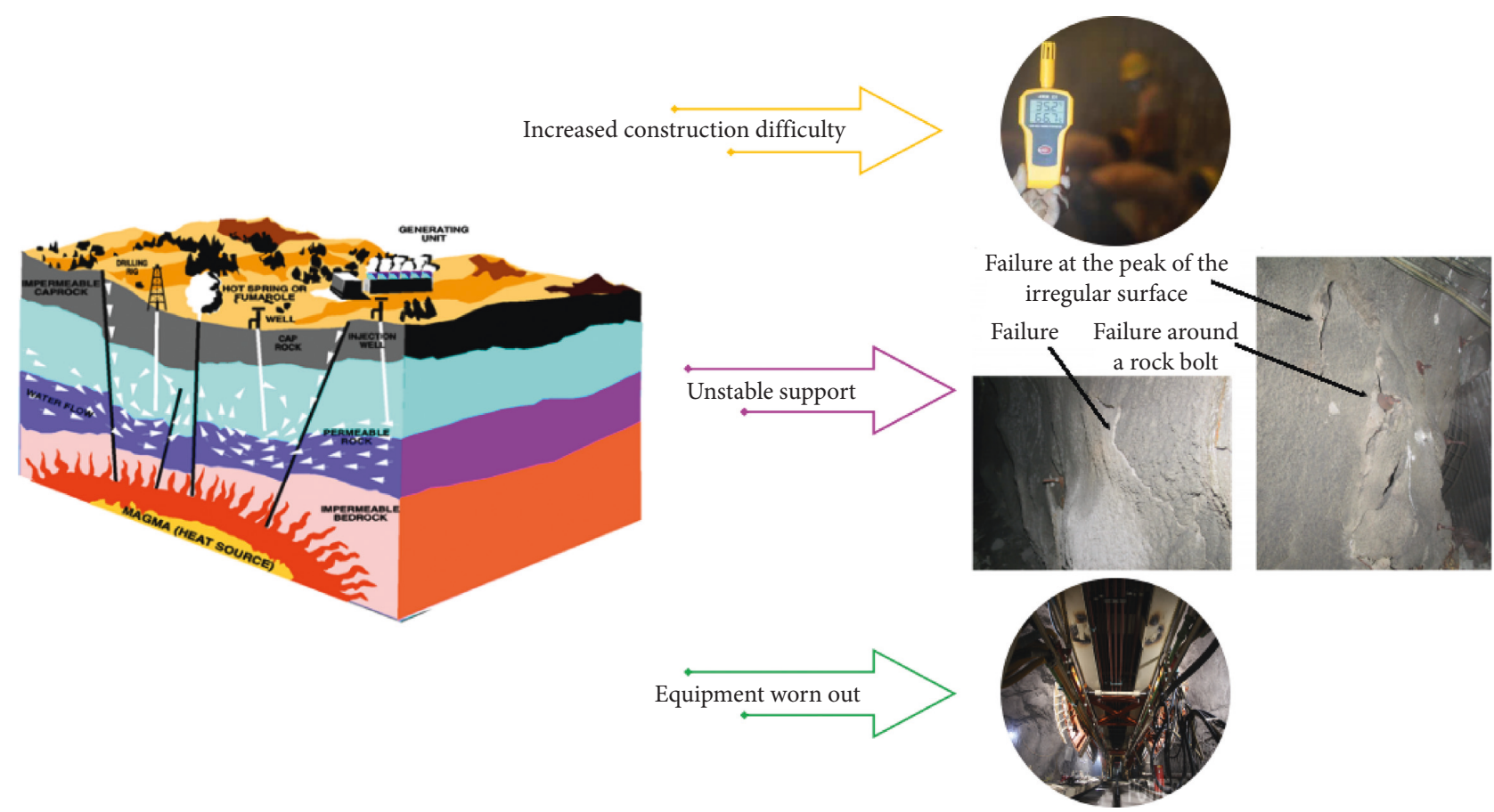

FIgURE 2: Causes and effects of terrestrial heat.

temperature when selecting materials. For example, the blast hole is affected by the temperature of the surrounding rock of the tunnel. In the hightemperature environment, there is a phenomenon where the dumb gun frequently explodes. This will cause serious safety hazards to the construction of the tunnel and will have an impact on the construction progress of the tunnel project.

\section{Effect of Temperature and Humidity on Adhesion Strength of Shotcrete-to-Rock}

Globally, there are few studies on the factors affecting the adhesion strength of shotcrete-to-rock. In highly geothermal environments, temperature and humidity become the most important factors affecting the adhesion strength of shotcrete-to-rock [1, 26-28]. In general, high-temperature 
geothermal tests are divided into two types: one is the case where the temperature is high and the humidity is large, and the other is the case where the temperature is high and the humidity is small. Relevant experts and scholars have basically conducted research on this part based on simulation experiments. Currently, most of the relevant experimental ideas are as follows: by simulating the actual hightemperature geothermal environment, changing the temperature and humidity conditions, and conducting field tests under other conditions with constant interference factors $[18,29,30]$. The test mainly uses the splitting method and the core drawing method to measure and analyse the adhesion strength of shotcrete-to-rock. The analysis of the test data shows that the temperature and humidity are the main factors affecting the adhesion strength of the shotcrete-torock [31, 32].

At present, in the study of the influence of temperature and humidity on the adhesion strength of shotcrete-to-rock, Tang [14] et al. used a novel indoor temperature and humidity control system to evaluate the effect of temperature and humidity on the adhesion strength of shotcrete-rock coupling. As Figure 3 shows, it can be noted that based on the data obtained under different working conditions, as the temperature increases from $50^{\circ} \mathrm{C}$ to $90^{\circ} \mathrm{C}$, the adhesion strength of shotcrete-to-rock decreases under all working conditions, and it can be noted that temperature had a significant effect on the adhesion strength, but it was not the only influencing factor [34-36]. As can be seen from the data in Figure 4, when the humidity increases from 25 to $90 \%$ under the same conditions, the adhesion strength of the shotcrete-to-rock interface will be significantly improved, and it can be found that, under the same humidity conditions, when the temperature rises to a certain limit, the longer the curing age, the lower the adhesion strength. When the rock-surface temperature reaches the critical point, as the age increases, the free water in the capillary pores of the adhesion surface will gradually disappear, hindering the hydration reaction to proceed, and the temperature stress causes the crack at the adhesion surface to expand continuously so that the older the shotcrete, the lower the adhesion strength [37, 38].

Similarly, Cui et al. [23] discussed the influence law and mechanism of sprayed concrete and rock bonding performance under dry heat conditions and pointed out that compared with the standard curing condition of $20^{\circ} \mathrm{C}$, the adhesion strength between shotcrete and rock under the condition of dry heat curing will be seriously reversed, and even the sprayed concrete and the rock will debond and crack. In the dry heat situation, water disperses quickly, the cement hydration stops early, the hydration product is not dense, strength of concrete is insufficient, and the drying shrinkage of concrete occurs under dry heat situation, so the adhesion strength between the sprayed concrete and the rock decreases under dry heat situation, and the indication in Figure 6 is the actual measurement result. Subsequently, Cui et al. found in the experiment that when the temperature rises to $35^{\circ} \mathrm{C}$, the shotcrete-to-rock adhesion strength is the highest because the concrete hydration reaction speed is faster; however, when the temperature rises to about $70^{\circ} \mathrm{C}$, the adhesion strength of the shotcrete-to-rock will be significantly reduced due to thermal damage caused by high temperature. In fact, in the same high-temperature and -humidity environment, the grade of concrete will also affect the adhesion strength of shotcrete-to-rock [39, 40]. It is known from the test data that the adhesion strength obtained when applying the C30 concrete test will be stickier than that obtained by applying C25 concrete because the cement content of C30 concrete is larger and the hydration reaction speed is faster. However, it is noteworthy that Cui et al. used a heated water tank and a heating box to simulate a temperature and humidity environment but did not spray concrete under a heated environment, which was different from the actual tunnel spray concrete, which affected the test results. To this end, Tang et al. [41] developed a temperature and humidity control system to simulate the temperature and humidity load under different working conditions of the tunnel, heating the rock beam through the heating device to achieve the required environmental conditions, and then spraying the concrete so as to get closer to the actual situation (Figure 5). Tang et al. obtained the adhesion strength of sprayed concrete and surrounding rock after 28 days of age (Figure 6) and proposed that the temperature has a great influence on the adhesion strength of shotcrete-to-rock. Under high-humidity conditions, the adhesion strength between sprayed concrete and surrounding rock decreases with the increase of temperature load, and under lowhumidity conditions, the higher the temperature, the faster the adhesion strength of shotcrete-to-rock decreases. This is because rock and shotcrete are different materials with a different modulus of elasticity; under the action of thermal load, the thermal deformation of sprayed concrete and surrounding rock is different, and with the increase of temperature, the shrinkage deformation is more obvious, so the adhesion strength of the shotcrete-to-rock is lower under high-temperature environment [42-44].

Under the same temperature and different humidity environment, the adhesion strength between sprayed concrete and surrounding rock is also different. With the increase of temperature, the influence of humidity on bond strength is more obvious. The adhesion strength values are nearly doubled, and the overall adhesion strength of the sprayed concrete is relatively high in high-humidity environments. This is mainly due to the fact that high environmental humidity tends to keep concrete moist and favors secondary hydration in the concrete, it is beneficial to replenish a certain amount of water inside the concrete, and the secondary hydration reaction of the concrete generates calcium silicate hydrate gel with cohesive force, which increased the cohesion of the rock-concrete interface to some extent. On the contrary, in an environment with a certain temperature and low humidity, the moisture inside the concrete will be lost due to the hydration reaction, and the hydrated calcium silicate gel supplements the capillary water on the concrete surface, which reduces the cohesive force of the gel and weakens the cohesion of the rock-concrete interface to some extent. On further research on shotcrete-torock adhesion strength, Tong et al. [24] believed that, in high-temperature tunnels, temperature and humidity will 


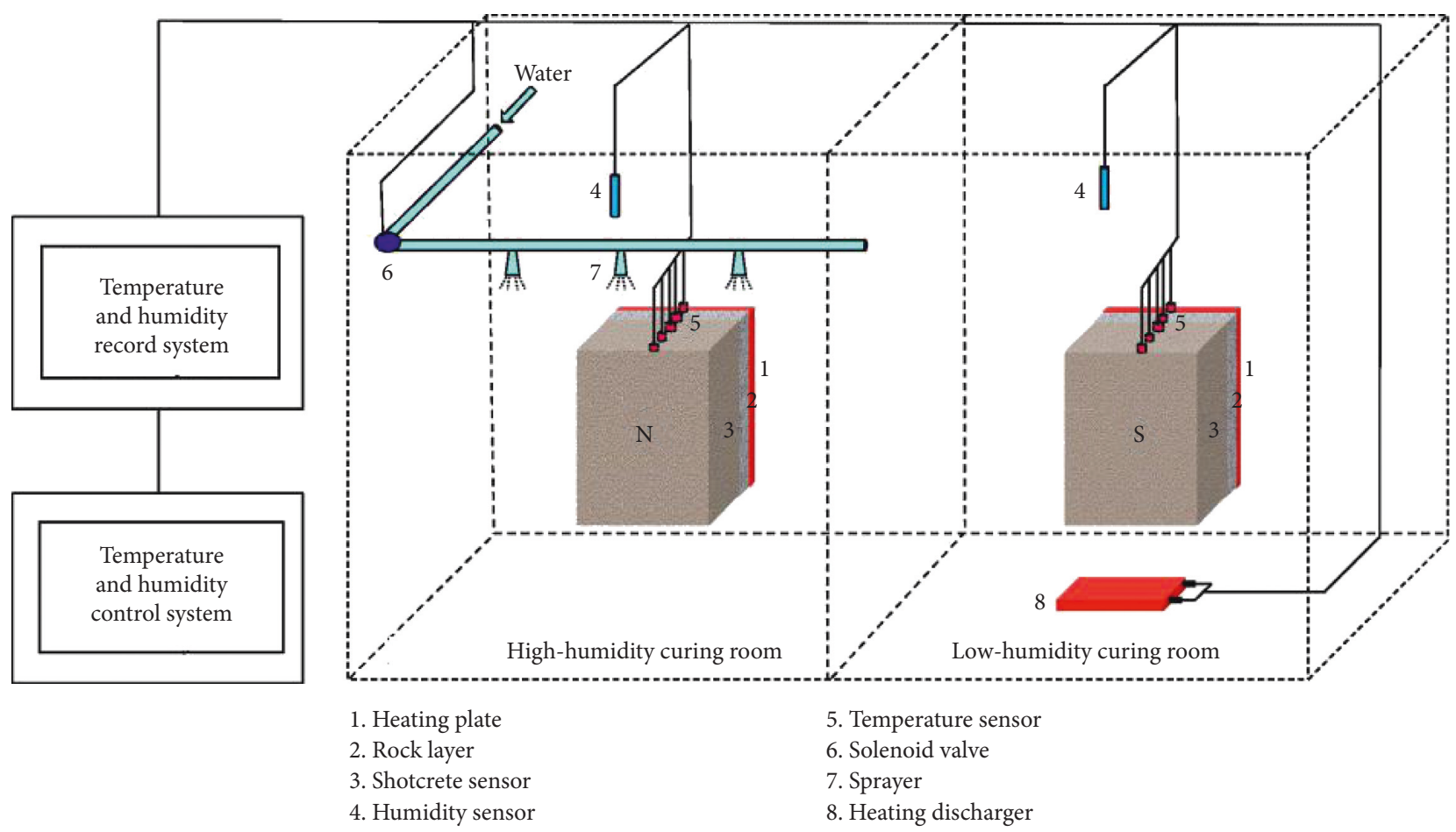

FIGURE 3: Indoor temperature and humidity control system [33].

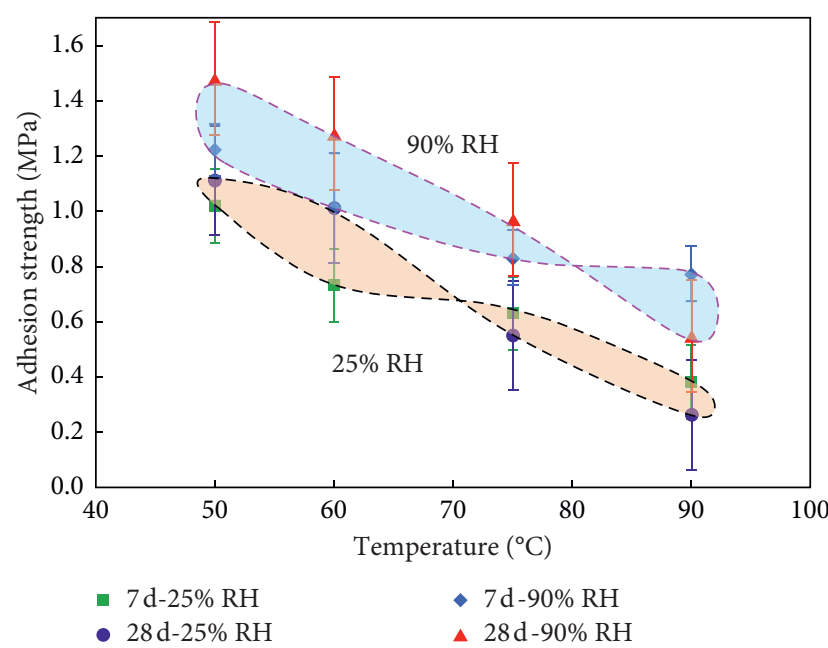

FIGURE 4: Effect of temperature and humidity on adhesion strength of shotcrete surrounded [33].

indirectly affect the speed and extent of concrete hydration, making rock-concrete interface failure; at this time, the degree of adhesion of the shotcrete-to-rock depends on the roughness of the interface, the rock-concrete interface is ineffective, and the degree of cohesion of the rock-concrete interface depends on the roughness of the interface (Figure 7). In order to better study the influence of temperature and humidity on the shotcrete-to-rock adhesion strength, it is generally necessary to clean the surface of the rock mass before the experiment to reduce the influence of the interface roughness $[10,36,45]$.

\section{Research Status of Microscopic Mechanism of Adhesion Strength}

Guo et al. [18] found in the study that the method of stereology can transform the plane gradient into a threedimensional gradient. As shown in Figure 7, the VG Studio Max 2.0 software is used to visualize the porosity distribution of the CT scan image, where red indicates a high interstice defect, and blue indicates a low interstice defect. Tang et al. [14] pointed out that, in the case of the same humidity, the temperature of the concrete is increased from $50^{\circ} \mathrm{C}$ to $90^{\circ} \mathrm{C}$, the porosity of the concrete will increase, and interstice defects will occur locally; on the contrary, the density of concrete under the condition of $25 \%$ humidity is significantly lower than the density of concrete under the condition of $25 \%$ humidity, and the void defect is more when the humidity is $25 \%$ (Table 2 ). The study believes that high temperature can accelerate the hydration reaction process of cement, leading to concrete shrinkage. In addition, under high-temperature conditions, cracks will occur in the interstice defect, resulting in a decrease in the adhesion strength of shotcrete-to-rock, especially at temperatures up to $75^{\circ} \mathrm{C}$, the interstice defects will suddenly increase, the shotcrete-to-rock adhesion strength will begin to fail, and the difference in concrete porosity and humidity will increase [46-48].

The research [41] used the scanning electron microscope to scan the interface rock and the sprayed concrete, respectively, and discussed the microscopic damage mechanism of the wet-heat environment to the concretesurrounding rock bond strength (Figures 8 and 9). The compactness of the microstructure of the concrete with the 


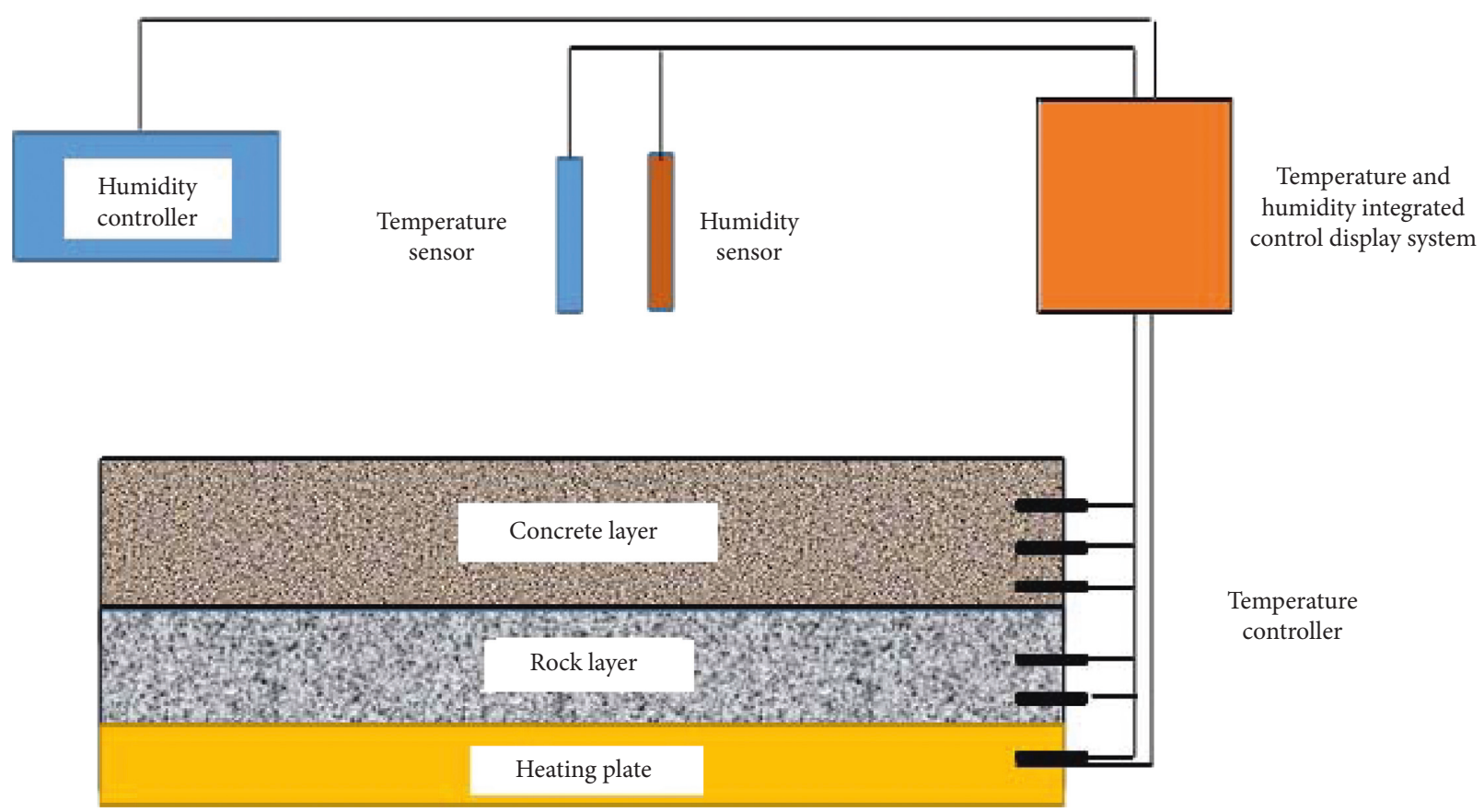

Figure 5: Temperature and humidity control system [42].

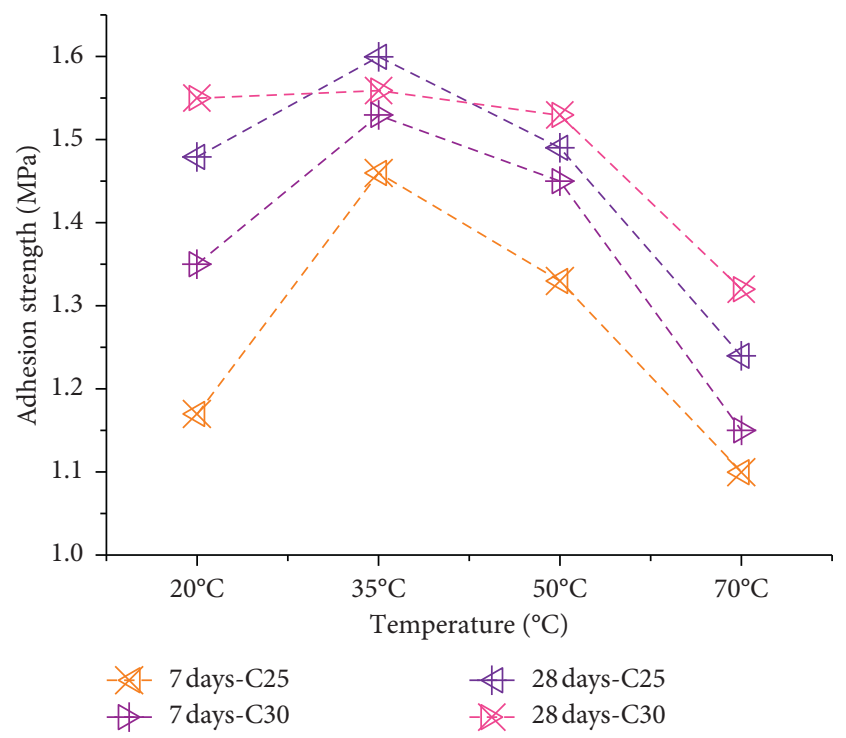

Figure 6: Effect of temperature and concrete grade on rockconcrete adhesion strength [25].

increase of temperature, but the denseness of the highhumidity environment, is better than that of the lowhumidity environment [49]. This is because the cement hydration is sufficient under high-humidity environment, the stopping speed is slow, and the degree of polymerization of the aluminum-oxygen tetrahedron and silicon-oxygen tetrahedron structure on the fly ash surface is relatively high and filled in the pores of the entire microaggregate. In low-humidity environment, the concrete is in a relatively dry environment, and the water inside the concrete is not dissipated quickly, especially at $90^{\circ} \mathrm{C}$; the shrinkage phenomenon is serious, and the higher the support temperature, the

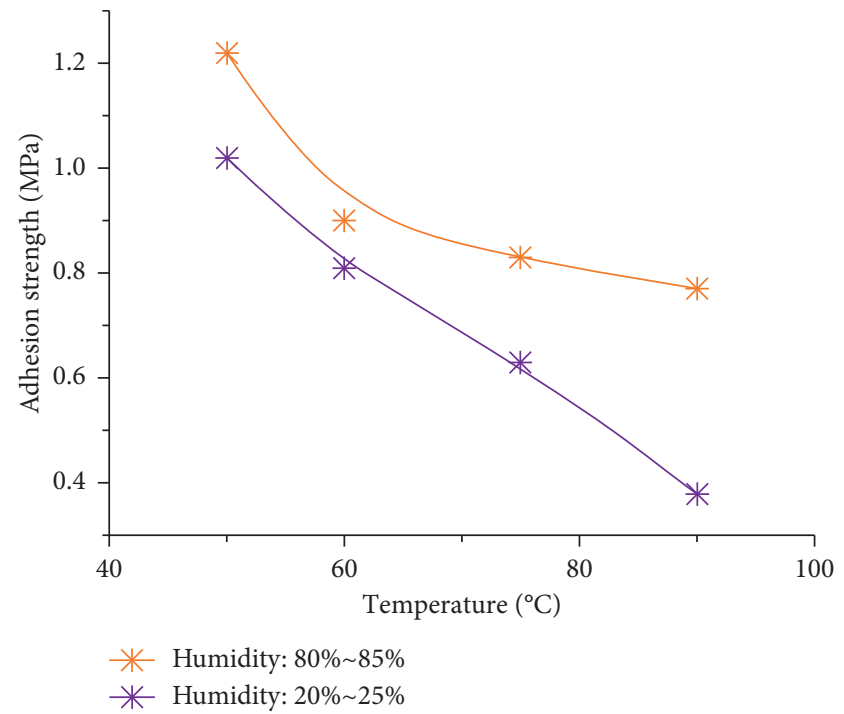

Figure 7: Test results of adhesion strength [12].

TABLE 2: Shotcrete porosity at various temperatures and humidities [33].

\begin{tabular}{lcccccccc}
\hline Working & N- & S- & N- & S- & N- & S- & N- & S- \\
condition & 50 & 50 & 50 & 50 & 50 & 50 & 50 & 50 \\
\hline Porosity (\%) & 2.33 & 2.58 & 2.69 & 2.74 & 3.81 & 5.6 & 6.2 & 7.29 \\
\hline
\end{tabular}

$\mathrm{N}$ : high-humidity curing; S: low-humidity curing.

faster the hydration reaction speed of the cement $[36,50]$. The formation rate of hydration products exceeds its migration speed and finally accumulates on the surface of cement granules, resulting in the loose porous surface and a large number of cracks in the concrete; therefore, the higher 


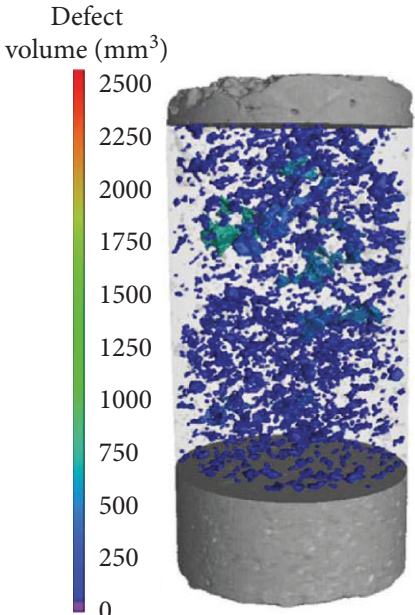

(a)

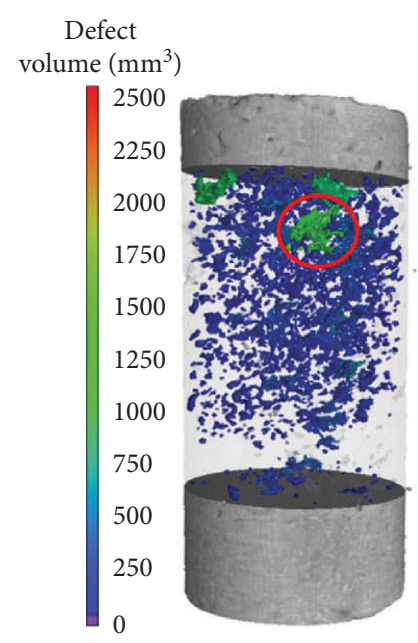

(b)

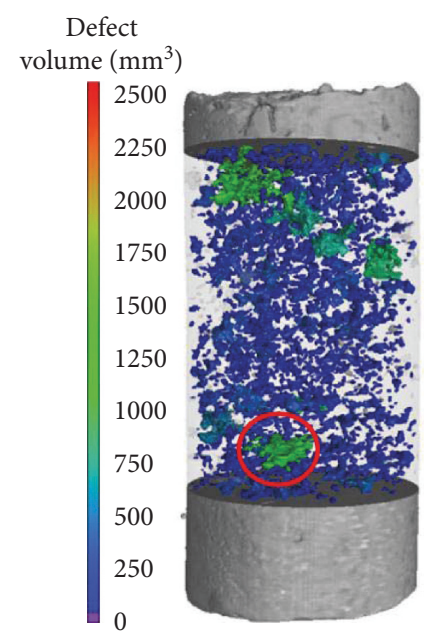

(c)

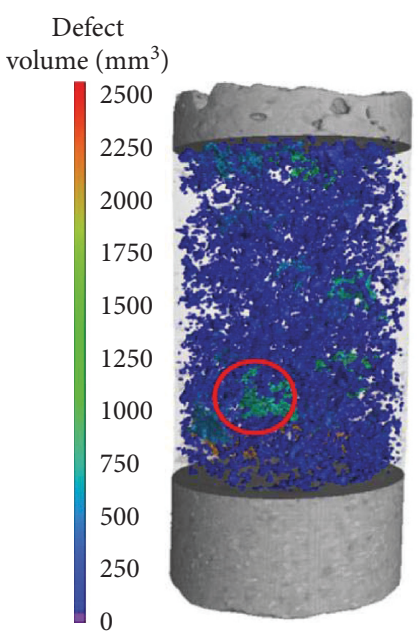

(d)

FIGURE 8: Shotcrete internal porosity distribution based on CT images at $90 \%$ humidity [33].

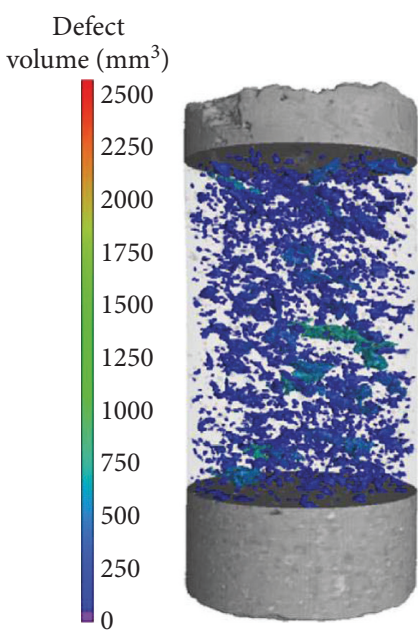

(a)

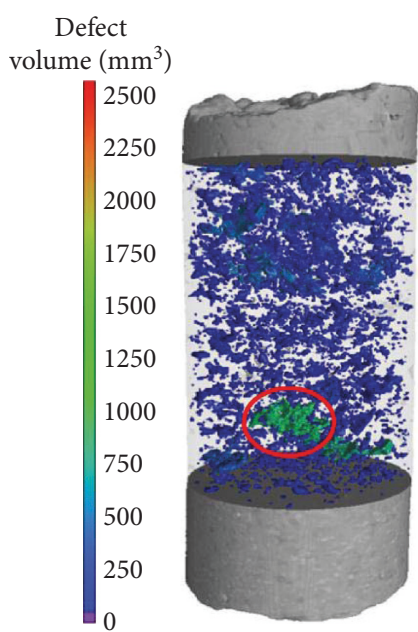

(b)

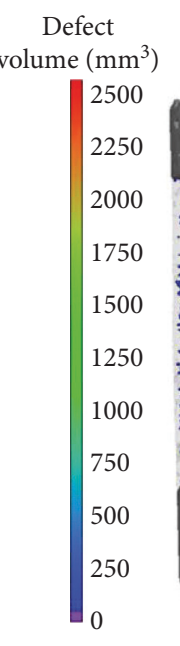

(c)
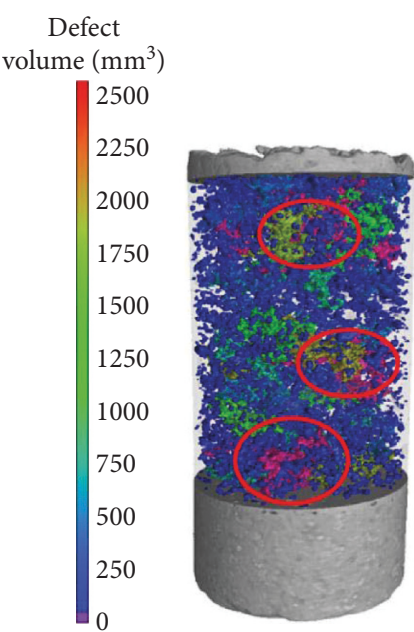

(d)

FIGURE 9: Shotcrete internal porosity distribution based on CT images at 25\% humidity [33].

the temperature in low-humidity environment, the lower the adhesion strength, and the greater the strength drop. Similarly, some scholars [15] believe that the temperature of the concrete can promote the shear strength of the structural surface within a certain temperature range. Because the temperature increases the degree of the hydration reaction, making the concrete and granite structural surface bond more closely. When the temperature is high, large pores appear inside the concrete, its structure is loose and porous, which seriously damages the bonding effect of the concrete, the damage is manifested in the part just exceeding the "bearing" range, and as the temperature continues to rise, the extent of damage continues to change. It is proposed that the microstructure change of concrete is consistent with its macroscopic mechanical properties. As the temperature increases, the concrete aggregate gradually becomes loose from compaction, the crack increases gradually, and the micromechanics properties also decrease [51, 52].
The influence of high temperature on the mechanical properties of concrete is much greater than the mechanical properties of granite; after experiencing high temperature, the granite and concrete, with the increase of the heating temperature, the peak stress, the elastic modulus decreases and the peak strain increases. When the temperature is lower than $400^{\circ} \mathrm{C}$, the mechanical properties of the granite change little and the concrete changes greatly $[53,54]$.

\section{Present Situation of Methods for Improving Concrete-Surrounding Rock Adhesion Strength of High-Rock Temperature Tunnel}

5.1. Comprehensive Cooling. With the rise of deep and long tunnel construction, the problem of high ground temperature has become increasingly prominent. In order to reduce the influence of high temperature on the adhesion strength 
of shotcrete-to-rock, comprehensive cooling measures are generally adopted internationally, and the statistics are as shown in Table 3 [55-58].

According to Table 3, the measures for comprehensive cooling of high-temperature tunnels are as follows: (1) ventilation cooling; (2) spray sprinkling cooling; (3) isolation high-temperature surrounding rock; (4) hot water prevention; (5) working surface artificial cooling and cooling; (6) other cooling measures and monitoring.

According to existing examples concerning tunnel cooling, the ventilation with cold air has two positive effects, as it is advantageous not only for the lining but also for the working conditions so that the total cost may even be reduced. It can reduce the influence of high temperature on the adhesion strength of shotcrete-to-rock and ensure the quality of shotcrete. The comprehensive management of hightemperature tunnels should fully consider the effectiveness and feasibility of cooling and should take into account factors such as engineering quantity and cost. Studies have shown that, after high-temperature surrounding rock excavation exposure, due to the influence of wind, the surrounding hightemperature surrounding rock is cooled correspondingly, and the temperature is continuously reduced. However, it is worth noting that the cooling and ventilation calculation process in addition to grasping the original temperature after excavation of the surrounding rock is also necessary to grasp the rock temperature at a certain distance from the face of the face after excavation exposure. The cooling process after excavation of surrounding rock is different due to different heat sources, different geological conditions, and different construction methods. Therefore, the influence of these factors should be fully considered in the tunnel design process to provide sufficient guarantee for cooling design, as shown in Figure 10 $[55,59]$.

5.2. Adding Admixture to Concrete. The inclusion of mineral admixture in the concrete can improve the performance of the concrete through the pozzolanic activity of the mineral admixture. The main advantages are reducing the heat of hydration and improving the resistance of the concrete to temperature cracking, improving the ultimate strength and impermeability of concrete due to the refinement of pores and the improvement of the interfacial transition zone, and improving the durability of concrete alkali-aggregate reaction expansion and sulfuric acid corrosion resistance [4, 60-64].

In order to improve the bonding strength of surrounding rock-concrete in high-temperature and high-humidity environment, Cui et al. [65] selected $70^{\circ} \mathrm{C}$ high-temperature and -humid environment (under the most unfavorable conditions) as the research object and replaced some cement with mineral admixture. Fly ash, slag powder, steel fiber, and polypropylene fiber are added to the raw materials (the raw materials are as shown in Table 4). The proportions of the mixed components added with the mineral admixture are shown in Table 5.

By measuring the bond strength of the mixture added to the admixture, Cui et al. found that the addition of the fiber material had little effect on the adhesion strength, but the addition of the mineral admixture significantly improved the adhesion strength of the shotcrete-to-rock. Through further observation of the microstructure of concrete, it was observed that when adding fly ash, the hydration structure density of concrete will be high, which greatly enhances the bond strength of surrounding rock-concrete in high-temperature and -humid environment [65]. Some studies have shown that fly ash can replace up to $60 \%$ of cement in structural concrete, and it has a good effect on the performance of fresh concrete or hardened concrete. Incorporating fly ash facilitates the dispersion of cement particles, enhances cement hydration, makes cement paste more homogeneous, reduces complex bleeding, and improves aggregate-cement paste adhesion. The fly ash particles react with $\mathrm{Ca}(\mathrm{OH})_{2}$ to form a hydrated calcium silicate colloid, which is beneficial to the improvement of concrete strength $[47,66,67]$.

Related studies have shown that slag is hydraulic and is a potentially gelatinous material. When slag is combined with fly ash, the strength of the concrete can be significantly improved due to their "synergy" in hydration, activity, and structural characteristics. However, under the special natural environment conditions of the high rock temperature tunnel, the influence of slag and fly ash on concrete strength has been rarely studied. He et al. [29] simulated hightemperature tunnel conditions in the laboratory to explore the effect of high rock temperature on the strength of fly ash concrete and slag-fly ash concrete. Table 6 shows the compressive strength of two admixture concretes under different curing conditions. The study found that, under standard curing conditions, the strength of slag-fly ash composite concrete is higher than that of single-filled fly ash concrete at all ages. Under the condition of relative humidity of $50 \%$, when the curing temperature is $50^{\circ} \mathrm{C}$, the strength of slag-fly ash composite concrete is higher than the strength of single fly ash concrete at all ages, and when the curing temperature exceeds $60^{\circ} \mathrm{C}$, the strength of the slag-fly ash composite concrete is lower than that of the single fly ash concrete. Subsequently, $\mathrm{He}$ et al. analysed the 3D XRD images of hydration of different mineral admixtures at different temperatures (Figures 11-13): As the temperature increases, the slag-fly ash sample generates more and more $\mathrm{Ca}(\mathrm{OH})_{2}$ than the fly ash sample. Under high-rock temperature tunnel conditions, when the temperature is lower than $50^{\circ} \mathrm{C}$, the slag-fly ash composite can increase the concrete strength more than the single fly ash, and when the temperature is higher than $60^{\circ} \mathrm{C}$, the single fly ash is more effective than the slag-fly ash composite to increase the strength of the concrete. Under the condition of high-rock temperature tunnel, the strength of concrete later is obviously reduced. This is not caused by the type and content of the hydration product of the cementitious material, but due to the early and intense accelerated reaction, the hydration products are not evenly spread, and the overlapping of each other is deteriorated, making the structure loose, which is not conducive to the later strength increase $[33,68,69]$.

5.3. Other Methods. The mineral [70] composition of the rock is not the only parameter controlling concrete-rock 
TABLE 3: Tunnel comprehensive cooling method statistics.

\begin{tabular}{lcc}
\hline Tunnel name & Project overview & Comprehensive measures \\
\hline Anfang Tunnel (Japan) & The water inrush temperature reaches $73^{\circ} \mathrm{C}$ & $\begin{array}{c}\text { (1) Chemical liquid grouting for } 2 \mathrm{~m} \text { outside } \\
\text { the upper half section of the tunnel } \\
\text { (2) Discharge the geothermal water with a } \\
\text { water pump }\end{array}$
\end{tabular}

The maximum temperature of the excavation surface reaches $67^{\circ} \mathrm{C}$

A water diversion tunnel in Xinjiang (China)

The maximum temperature in the drilling hole is $82^{\circ} \mathrm{C}$

\section{(1) Spray watering}

(2) Set up drilling equipment with its own circulating water

(3) Reasonably arrange the high-temperature operation

The ambient temperature after blasting is $48^{\circ} \mathrm{C}$

(1) The spray cooling system is used to cool the environment inside the cave

Niangyong hydropower station diversion tunnel (China)

The temperature of the rock surface is $52^{\circ} \mathrm{C}$

(2) Cooling circulation system is used to cool the blast hole of the excavation face

\section{(1) Spray watering}

(2) Insulate high-temperature surrounding rock and add $0.03 \%$ high efficiency airentraining agent to spray concrete

Luquan lead factory diversion tunnel (China)
The temperature of the local surrounding rock is $76^{\circ} \mathrm{C}$
(3) For the digging puddles in the high-water temperature section, the water pump is used to discharge the hot water

(4) Transporting ice cubes to the excavation surface

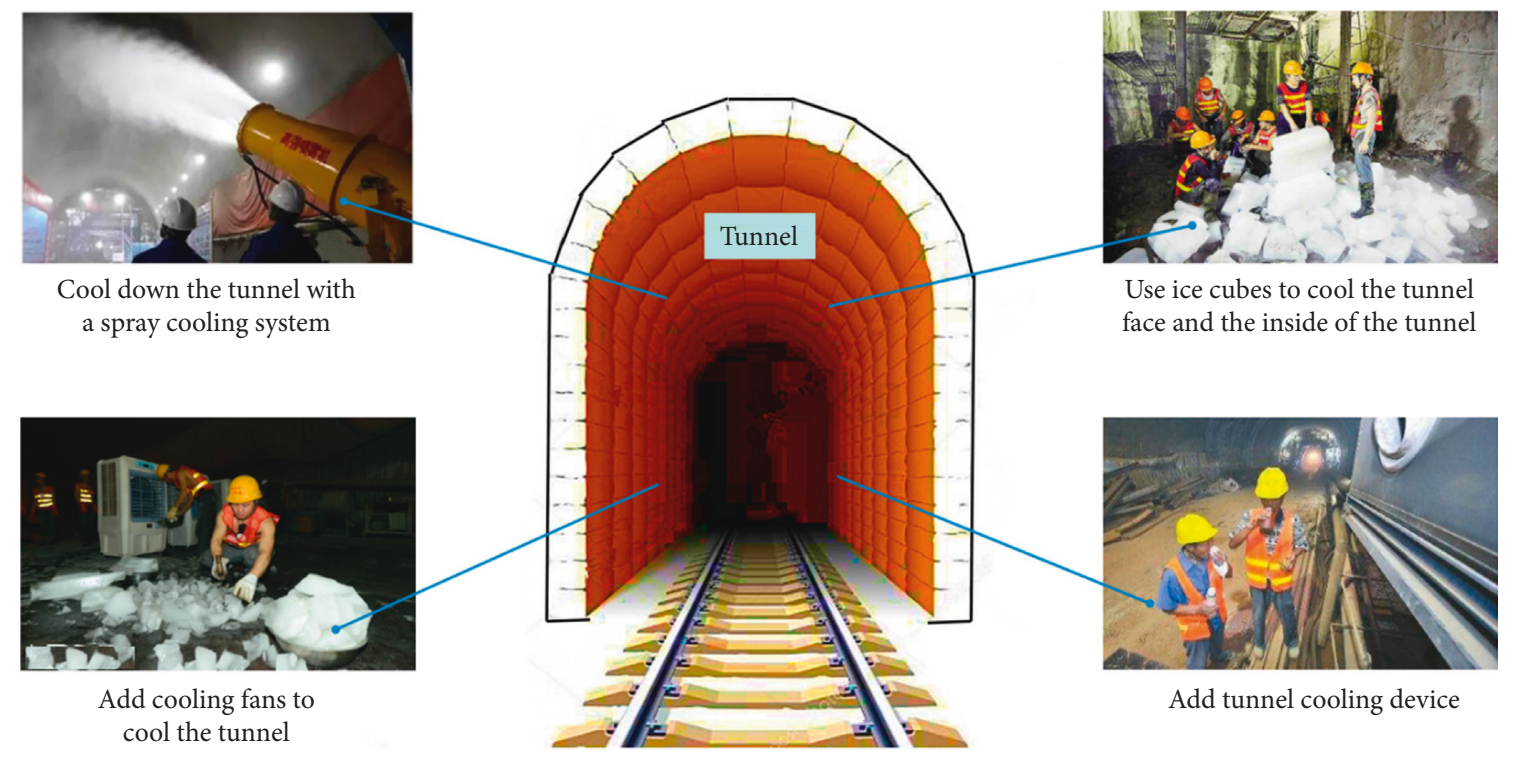

FIGURE 10: Integrated cooling method inside the tunnel.

TABLE 4: Raw materials of wet-sprayed shotcrete [47].

\begin{tabular}{lccccc}
\hline Material & Cement & Sand & Gravel & Water reducer & Accelerated agent \\
Type & P.O42.5R & $\begin{array}{c}\text { Machine-made sand, medium sand } \\
\text { with } \\
12 \% \text { stone powder content }\end{array}$ & $\begin{array}{c}5-15 \mathrm{~mm} \\
\text { continuous } \\
\text { grading }\end{array}$ & $\begin{array}{c}\text { TK-SP polycarboxylic acid } \\
\text { type }\end{array}$ & $\begin{array}{c}\text { Alkali-free liquid BASF } \\
\text { type }\end{array}$ \\
\hline
\end{tabular}

adhesion because surface texture plays a critical role as well (Figure 14 [72]).

In order to study the influence of the interface roughness between rock mass and concrete on the cohesive force, Luo et al. [73] selected several groups of products with the same interface rough sawtooth width "l" and a different sawtooth depth " $h$ " as the research object. Studies have shown that the sawtooth depth " $h$ " has a greater impact on the interfacial 
TABLE 5: Designed mix proportions for the bond strength improvement test [47].

\begin{tabular}{|c|c|}
\hline Designed mix proportions & Description \\
\hline $\mathrm{BP}$ & $\begin{array}{l}\text { Basic mix proportion (no mineral admixture or the } \\
\text { fiber material): cement: } 400 \mathrm{~kg} / \mathrm{m}^{3} \text {; sand: } 814 \mathrm{~kg} / \mathrm{m}^{3} \text {; } \\
\text { gravel: } 666 \mathrm{~kg} / \mathrm{m}^{3} \text {; water: } 200 \mathrm{~kg} / \mathrm{m}^{3} \text {; accelerator: } \\
\qquad 20 \mathrm{~kg} / \mathrm{m}^{3}\end{array}$ \\
\hline $25 \% \mathrm{SP}$ & $25 \%$ of cement replaced by slag powder \\
\hline $25 \% \mathrm{FA}$ & $25 \%$ of cement replaced by fly ash \\
\hline SF & $1 \%$ (volume ratio) of steel fiber mixed \\
\hline $\mathrm{PF}$ & $0.9 \mathrm{~kg} / \mathrm{m}^{3}$ of polypropylene fiber mixed \\
\hline $\mathrm{DF}$ & $\begin{array}{c}\text { Double mix of } 1 \% \text { (volume ratio) of steel fibers and } \\
0.9 \mathrm{~kg} / \mathrm{m}^{3} \text { of polypropylene fiber }\end{array}$ \\
\hline
\end{tabular}

TABLE 6: Compressive strength of two admixture concrete under different curing conditions [22, 68].

\begin{tabular}{lcccccccc}
\hline & \multicolumn{2}{c}{$20^{\circ} \mathrm{C}+95 \% \mathrm{RH}$} & \multicolumn{2}{c}{$50^{\circ} \mathrm{C}+50 \% \mathrm{RH}$} & \multicolumn{2}{c}{$60^{\circ} \mathrm{C}+50 \% \mathrm{RH}$} & \multicolumn{2}{c}{$80^{\circ} \mathrm{C}+50 \% \mathrm{RH}$} \\
Age & $\begin{array}{c}\text { Adding fly } \\
\text { ash }\end{array}$ & $\begin{array}{c}\text { Adding slag + fly } \\
\text { ash }\end{array}$ & $\begin{array}{c}\text { Adding fly } \\
\text { ash }\end{array}$ & $\begin{array}{c}\text { Adding slag +fly } \\
\text { ash }\end{array}$ & $\begin{array}{c}\text { Adding fly } \\
\text { ash }\end{array}$ & $\begin{array}{c}\text { Adding slag + fly } \\
\text { ash }\end{array}$ & $\begin{array}{c}\text { Adding fly } \\
\text { ash }\end{array}$ & $\begin{array}{c}\text { Adding slag + fly } \\
\text { ash }\end{array}$ \\
\hline $3 \mathrm{~d}$ & 26.2 & 27.0 & 31.3 & 34.5 & 33.8 & 32.9 & 38.0 & 31.4 \\
$7 \mathrm{~d}$ & 39.4 & 43.1 & 35.7 & 39.6 & 36.2 & 35.8 & 39.6 & 34.7 \\
$28 \mathrm{~d}$ & 47.3 & 52.5 & 44.1 & 48.0 & 42.3 & 38.1 & 41.5 & 37.7 \\
$60 \mathrm{~d}$ & 50.6 & 55.2 & 48.2 & 52.2 & 47.0 & 43.5 & 43.1 \\
\hline
\end{tabular}

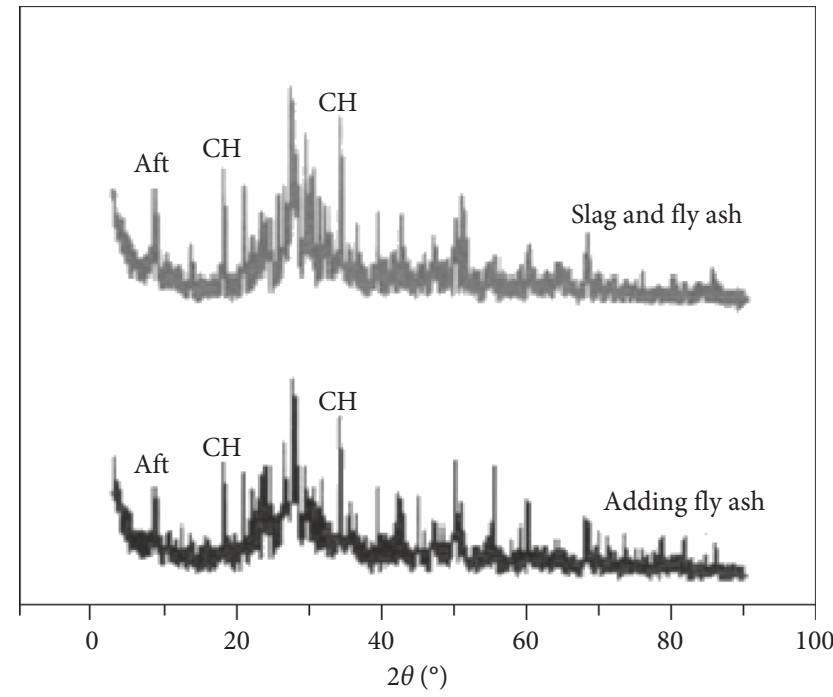

FIGURE 11: XRD pattern of 3D hydration of different mineral admixtures at $20^{\circ} \mathrm{C}$ [68].

cohesion, and the rough rock surface affects the mechanical behaviour of the concrete (Figure 15). However, there is no quantitative discussion of the effect of roughness on the interface bearing capacity $[71,74,75]$. Roughness, as an indicator of rock mechanics, plays an important role in studying the mechanical properties of rock contact surface, and it mainly controls the degree of undulation of the contact surface, which in turn affects the shear bite force and frictional resistance [76-81]. Subsequently, the position of the shear plane will also change, ultimately affecting the change in the failure mode. Therefore, in order to improve the adhesion strength of the shotcrete-to-rock, the roughness of the surface of the rock mass should be appropriately

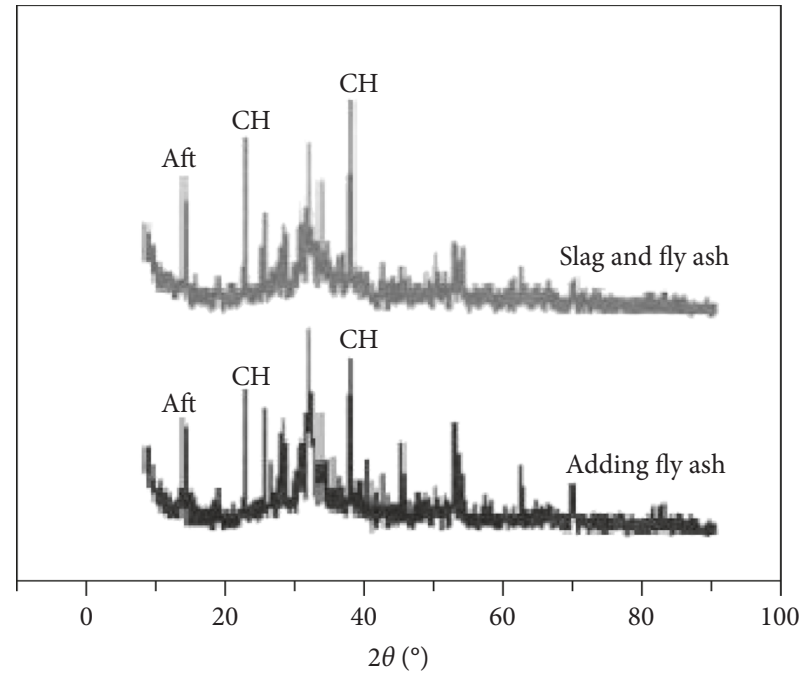

Figure 12: XRD pattern of 3D hydration of different mineral admixtures at $50^{\circ} \mathrm{C}[68]$.

increased to improve the bite strength. Bai et al. [82] selected styrene and polyurethane insulation materials to analyse the heat insulation effect and the corresponding consumption of cold energy. The relevant parameters of the calculation are as follows (Table 7).

Through calculation and comparison of the results, it can be seen that the amount of refrigerant required for not providing the heat insulation layer is larger than that of the setting, and the amount of refrigerant required for styrene as the heat insulation layer is larger than that of the polyurethane [83-89]. In addition, the phase transition point of liquid nitrogen is lower than that of ice, and the cooling effect as a refrigerant is better than that of ice, but the 


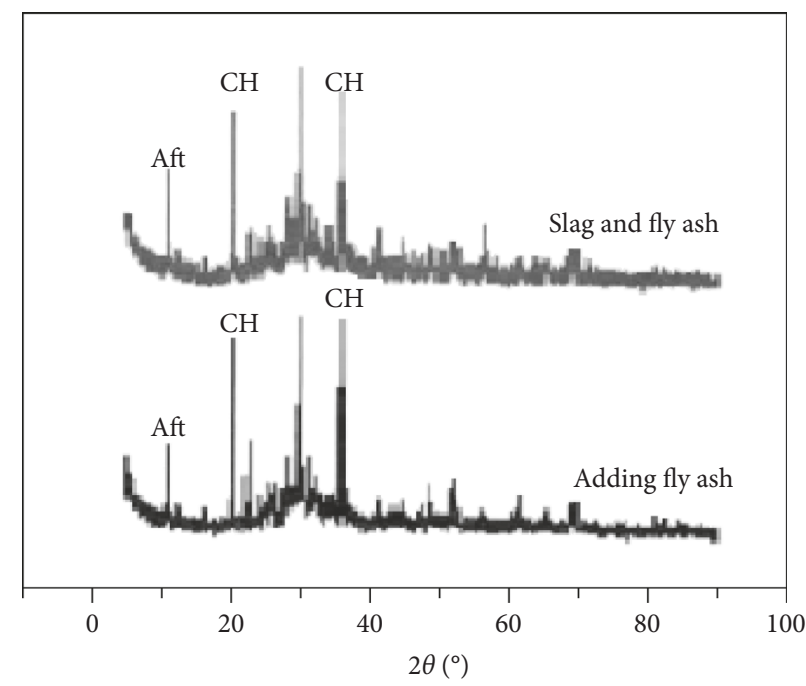

FIGURE 13: XRD pattern of 3D hydration of different mineral admixtures at $80^{\circ} \mathrm{C}$ [68].

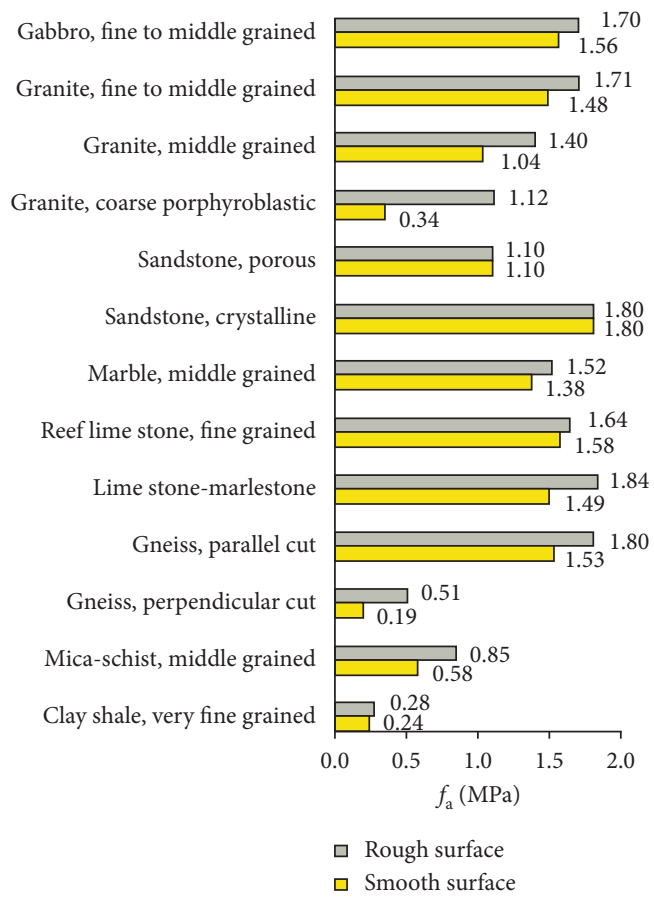

FIGURE 14: Effect of rock surface roughness on rock-concrete adhesion strength [71].

production cost of liquid nitrogen is higher than that of ice (Tables 8 and 9) [90-103].

\section{Conclusion}

(1) Tunnelling in severe geothermal conditions is becoming a worldwide problem, and the engineering community is starting to pay more attention to the effect of geothermal heat on tunnels, during both the construction and the service life. While the geothermal heat can be in some way controlled in the short term, the long-term effects on tunnel resistance and durability are still open to investigation.
(2) According to relevant experiments, the factors affecting the adhesion strength of surrounding rockconcrete mainly include temperature and humidity, roughness, and maintenance degree of contact surface and mineral composition of rock. In fact, the failure of the cohesive force at the surrounding rockconcrete interface is a comprehensive process, and the comprehensive evaluation system should be established by considering the influential proportion of each factor.

(3) Regarding the local mechanisms adhesion, it is well known that the thermal deformations of the concrete lining and of the surrounding rock are different. 


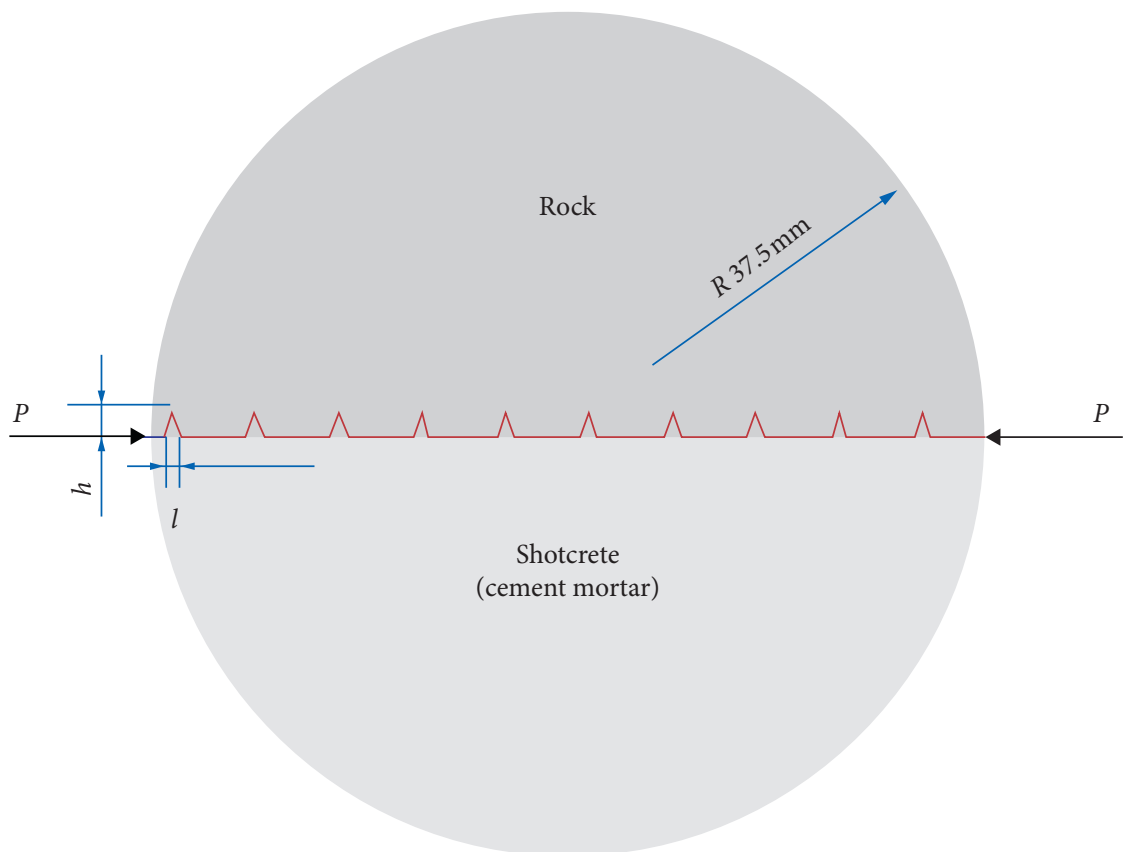

Figure 15: Microcontact interface between rock mass and concrete [74].

TABLe 7: Material parameters [78].

\begin{tabular}{lcc}
\hline Material & Density $\left(\mathrm{kg} / \mathrm{m}^{3}\right)$ & Thermal conductivity $(\mathrm{W} /(\mathrm{m} \cdot \mathrm{K}))$ \\
\hline Surrounding rock (granite) & 2800 & 3.49 \\
Lining (concrete) & 2300 & 1.51 \\
Styrene & 25 & 0.0356 \\
Polyurethane & 32 & 0.0222 \\
Air & 1.293 & 0.03 \\
\hline
\end{tabular}

TABLE 8: Refrigerant thermal physical coefficient [78].

\begin{tabular}{lcccc}
\hline Refrigerant & Density $\left(\mathrm{kg} / \mathrm{m}^{3}\right)$ & Thermal conductivity $\left(\mathrm{W} / \mathrm{m} \cdot{ }^{\circ} \mathrm{C}\right)$ & Specific heat capacity $\left(\mathrm{J} /\left(\mathrm{kg} \cdot{ }^{\circ} \mathrm{C}\right)\right)$ & Phase change point $\left({ }^{\circ} \mathrm{C}\right)$ \\
\hline Ice & 917 & 2.4000 & 2060 & -4.0 \\
Liquid nitrogen & 820 & 0.0933 & 2016 & -195.8 \\
\hline
\end{tabular}

Table 9: Comparison of refrigerant consumption $\mathrm{kg} /(\mathrm{m} \cdot \mathrm{h})$ [78].

\begin{tabular}{lcccccc}
\hline Refrigerant & Geothermal $\left({ }^{\circ} \mathrm{C}\right)$ & No heat insulation & $10 \mathrm{~cm}$ styrene & $10 \mathrm{~cm}$ polyurethane & $5 \mathrm{~cm}$ styrene & $5 \mathrm{~cm}$ polyurethane \\
\hline Ice & 100 & 34.84 & 19.80 & 15.52 & 25.34 & 21.38 \\
Ice & 60 & 15.36 & 8.71 & 6.97 & 11.09 & 9.50 \\
Liquid nitrogen & 100 & 5.09 & 2.89 & 2.27 & 3.70 & 3.12 \\
Liquid nitrogen & 60 & 2.24 & 1.27 & 1.02 & 1.62 & 1.39 \\
\hline
\end{tabular}

Concrete undergoes large thermal deformations at high temperature, as cement hydration is enhanced, followed by cracking inside the concrete mass and loss of adhesion between the lining and the rock. Some scholars think that $75^{\circ} \mathrm{C}$ is a sort of critical temperature, above which adhesion is lost.

(4) The inclusion of mineral admixture in the concrete can improve the performance of the concrete through the pozzolanic activity of the mineral admixture. A large number of experiments have been carried out to study the application of fly ash and mineral powder in shotcrete. When the dosage is within the proper range, it will help to improve the strength of concrete. At the same time, the incorporation of different admixtures can also improve the mechanical properties of concrete.

(5) In this paper, the existing methods for improving the adhesion are compared by studying the influencing 
factors of shotcrete-to-rock adhesion and microscopic damage mechanism. The comprehensive cooling measures can directly perform air cooling in the tunnel, but the actual operability is not strong. The key to high-ground temperature construction is that the ventilation is cold enough and the air volume is large enough, which will require a large cost.

\section{Conflicts of Interest}

The authors declare that there are no conflicts of interests regarding the publication of this paper.

\section{Acknowledgments}

This work was financially supported by the Project on Social Development of Shaanxi Provincial Science and Technology Department (nos. 2018SF-382 and 2018SF-378), the Special Fund for Basic Scientific Research of Central Colleges of Chang'an University (nos. 310821172004, 310821153312, 310821165011, and 310821173312), and the National Key R\&D problem of China (no. 2017YFC0805306).

\section{References}

[1] C.-H. Lee, T.-T. Wang, and H.-J. Chen, "Experimental study of shotcrete and concrete strength development in a hot spring environment," Tunnelling and Underground Space Technology, vol. 38, pp. 390-397, 2013.

[2] J. Wang, D. Niu, S. Ding, Z. Mi, and D. Luo, "Microstructure, permeability and mechanical properties of accelerated shotcrete at different curing age," Construction and Building Materials, vol. 78, pp. 203-216, 2015.

[3] S. Wang, Y. Jian, X. Lu, L. Ruan, W. Dong, and K. Feng, "Study on load distribution characteristics of secondary lining of shield under different construction time," Tunnelling and Underground Space Technology, vol. 89, pp. 2537, 2019.

[4] M. P. Hochstein and W. M. Prebble, "Major engineering constructions on top of a high-temperature geothermal system: problems encountered at Tokaanu, New Zealand," Geothermics, vol. 35, no. 4, pp. 428-447, 2006.

[5] W. Dong, D. Yang, X. Zhou, G. Kastiukas, and B. Zhang, "Experimental and numerical investigations on fracture process zone of rock-concrete interface," Fatigue \& Fracture of Engineering Materials \& Structures, vol. 40, no. 5, pp. 820-835, 2017.

[6] R. Pöttler, "Time-dependentrock-Shotcrete interaction a numerical shortcut," Computers and Geotechnics, vol. 9, no. 3, pp. 149-169, 1990.

[7] L. D. Suits, T. C. Sheahan, J. P. Seidel, and C. M. Haberfield, "Laboratory testing of concrete-rock joints in constant normal stiffness direct shear," ASTM Geotechnical Testing Journal, vol. 25, no. 4, pp. 391-404, 2002.

[8] G.-J. Bae, S.-H. Chang, S.-W. Lee, and H.-G. Park, "Evaluation of interfacial properties between rock mass and shotcrete," International Journal of Rock Mechanics and Mining Sciences, vol. 41, pp. 106-112, 2004.

[9] H. Yilmaz, "Shear-bond strength testing of thin spray-on liners," Journal of South African Institute of Mining and Metallurgy, vol. 107, pp. 519-530, 2007.
[10] M. Son, "Adhesion strength at the shotcrete-rock contact in rock tunneling," Rock Mechanics and Rock Engineering, vol. 46, no. 5, pp. 1237-1246, 2013.

[11] Z. Y. Liu, "Experimental study on the formulation of shotcrete materials in high temperature and high humidity environment," Science and Technology of West China, vol. 7, pp. 1-3, 2008.

[12] X. B. Wang, W. J. Wang, Y. B. Xia et al., "Research on concrete lining construction technology of plateau geothermal tunnel," Chinese Railways, pp. 52-55, 2012.

[13] G. Mainali, S. Dineva, and E. Nordlund, "Experimental study on debonding of shotcrete with acoustic emission during freezing and thawing cycle," Cold Regions Science and Technology, vol. 111, pp. 1-12, 2015.

[14] Y. Tang, G. Xu, J. Lian, H. Su, and C. Qu, "Effect of temperature and humidity on the adhesion strength and damage mechanism of shotcrete-surrounded rock," Construction and Building Materials, vol. 124, pp. 1109-1119, 2016.

[15] L. T. Phan and N. J. Carino, "Review of mechanical properties of HSC at elevated temperature," Journal of Materials in Civil Engineering, vol. 10, no. 1, pp. 58-65, 1998.

[16] H.-J. Chen, T.-Y. Yang, and C.-W. Tang, "Strength and durability of concrete in hot spring environments," Computers \& Concrete, vol. 6, no. 4, pp. 269-280, 2009.

[17] C. Y. Dong, "Shear properties and constitutive relation of jetconcrete and granite surrounding rock in high rock temperature tunnel," Master's thesis, Southwest Jiaotong University, Chengdu, China, in Chinese, 2017.

[18] Q. Guo, Y. Bian, L. Li, Y. Jiao, J. Tao, and C. Xiang, "Stereological estimation of aggregate gradation using digital image of asphalt mixture," Construction and Building Materials, vol. 94, pp. 458-466, 2015.

[19] Y. Fang, Z. Chen, L. Tao, J. Cui, and Q. Yan, "Model tests on longitudinal surface settlement caused by shield tunnelling in sandy soil," Sustainable Cities and Society, vol. 47, article 101504, 2019.

[20] Z. J. Zhou, C. N. Ren, G. J. Xu, H. C. Zhan, and T. Liu, "Dynamic failure mode and dynamic response of high slope using shaking table test," Shock and Vibration, vol. 2019, Article ID 4802740, 19 pages, 2019.

[21] X. L. Luo, D. Y. Li, Y. Yang, and S. R. Zhang, "Spatiotemporal traffic flow prediction with knn and lstm," Journal of Advanced Transportation, vol. 2019, Article ID 4145353, 10 pages, 2019.

[22] P. Bamonte, P. G. Gambarova, and A. Nafarieh, "Hightemperature behavior of structural and non-structural shotcretes," Cement and Concrete Composites, vol. 73, pp. 42-53, 2016.

[23] S. A. Cui, J. W. Li, Y. Z. Ye et al., "Bonding strength of shotcrete and rock in dry-heat environment of hightemperature tunnel," Journal of Building Materials, vol. 16, pp. 663-666, 2013.

[24] J. Tong, M. Karakus, M. Wang, C. Dong, and X. Tang, "Shear strength characteristics of shotcrete-rock interface for a tunnel driven in high rock temperature environment," Geomechanics and Geophysics For Geo-Energy and Geo-Resources, vol. 2, no. 4, pp. 331-339, 2016.

[25] Y. Fan, S. A. Cui, T. Chen, and Z. H. Zhou, "Experiment study on mechanical properties of shotcrete under heat injury environment of high ground temperature tunnel," Advanced Materials Research, vol. 785-786, pp. 291-294, 2013. 
[26] C. S. Yang, "Research on comprehensive construction technology of high ground temperature tunnel," Railway construction technology, pp. 39-46, 2010, in Chinese.

[27] L. Li, A.-X. Wu, Y.-M. Wang, B. Han, H.-J. Wang, and C.-L. Wang, "Mechanism of wet shotcrete interacting with rock in support systems," Journal of Central South University, vol. 20, no. 3, pp. 821-829, 2013.

[28] J. Wang, D. Niu, and Y. Zhang, "Mechanical properties, permeability and durability of accelerated shotcrete," Construction and Building Materials, vol. 95, pp. 312-328, 2015.

[29] T. S. He, J. T. Ji, Y. Wang et al., "Effect of mineral admixture on mechanical properties of concrete in high rock temperature tunnel," Materials Review, vol. 27, pp. 119-122, 2013, in Chinese.

[30] Z.-F. Wang, W.-C. Cheng, and Y.-Q. Wang, "Investigation into geohazards during urbanization process of Xi'an, China," Natural Hazards, vol. 92, no. 3, pp. 1937-1953, 2018.

[31] Y.-Q. Wang, S. Xu, R. Ren, S. Zhang, and Z. Ren, "Application of the twin-tube complementary ventilation system in large-slopping road tunnels in China," International Journal of Ventilation, pp. 1-20, 2019.

[32] S. Krishnaiah, D. N. Singh, and G. N. Jadhav, "A methodology for determining thermal properties of rocks," International Journal of Rock Mechanics and Mining Sciences, vol. 41, no. 5, pp. 877-882, 2004.

[33] L. E. Bryne, A. Ansell, and J. Holmgren, "Laboratory testing of early age bond strength of shotcrete on hard rock," Tunnelling and Underground Space Technology, vol. 41, pp. 113-119, 2014.

[34] Q. J. Ma, Y. Duan, H. Su et al., "Analysis of influence of different rock wall temperatures on bonding strength of surrounding rock and shotcrete," Water Conservancy and Hydropower Technology, vol. 46, pp. 62-65, 2015, in Chinese.

[35] L. Ahmed and A. Ansell, "Vibration vulnerability of shotcrete on tunnel walls during construction blasting," Tunnelling and Underground Space Technology, vol. 42, pp. 105-111, 2014.

[36] Y. Wu and $\mathrm{B}$. Wu, "Residual compressive strength and freeze-thaw resistance of ordinary concrete after high temperature," Construction and Building Materials, vol. 54, pp. 596-604, 2014.

[37] L. Malmgren and E. Nordlund, "Interaction of shotcrete with rock and rock bolts-a numerical study," International Journal of Rock Mechanics and Mining Sciences, vol. 45, no. 4, pp. 538-553, 2008.

[38] S. Cui, P. Liu, E. Cui, J. Su, and B. Huang, "Experimental study on mechanical property and pore structure of concrete for shotcrete use in a hot-dry environment of high geothermal tunnels," Construction and Building Materials, vol. 173, pp. 124-135, 2018.

[39] Y. Tang, H. Su, H. Zhang et al., "Bonding concretesurrounding rock bond strength and microscopic failure mechanism in high-temperature tunnel," Water Resources and Power, in Chinese, 2015.

[40] Y. N. Chan, G. F. Peng, and M. Anson, "Residual strength and pore structure of high-strength concrete and normal strength concrete after exposure to high temperatures," Cement and Concrete Composites, vol. 21, no. 1, pp. 23-27, 1999.

[41] Y. Tang, H. Su, S. Huang, C. Qu, and J. Yang, "Effect of curing temperature on the durability of concrete under highly geothermal environment," Advances in Materials Science and Engineering, vol. 2017, Article ID 7587853, 9 pages, 2017.
[42] Z. Zhang, H. Zhang, Y. Tan, and H. Yang, "Natural wind utilization in the vertical shaft of a super-long highway tunnel and its energy saving effect," Building and Environment, vol. 145, pp. 140-152, 2018.

[43] A. H. Akca and N. Özyurt Zihnioğlu, "High performance concrete under elevated temperatures," Construction and Building Materials, vol. 44, pp. 317-328, 2013.

[44] J. W. Bullard, H. M. Jennings, R. A. Livingston et al., "Mechanisms of cement hydration," Cement and Concrete Research, vol. 41, no. 12, pp. 1208-1223, 2011.

[45] J. Wang, Q. Huo, Z. Song, and Y. Zhang, "Study on adaptability of primary support arch cover method for largespan embedded tunnels in the upper-softlower-hard stratum," Advances in Mechanical Engineering, vol. 11, no. 1, article 168781401882537, 2019.

[46] J. Qiu, Y. Qin, Z. H. Feng, L. Wang, and K. Wang, "Safety risks and protection measures for the city wall during the construction and operation of Xi'an Metro," Journal of Performance of Constructed Facilities, vol. 33, no. 5, p. 12, 2019.

[47] A. Sjölander and A. Ansell, "Investigation of non-linear drying shrinkage for end-restrained shotcrete of varying thickness," Magazine of Concrete Research, vol. 70, no. 6, pp. 271-279, 2018.

[48] G. Chen, T. Li, G. Zhang, H. Yin, and H. Zhang, "Temperature effect of rock burst for hard rock in deep-buried tunnel," Natural Hazards, vol. 72, no. 2, pp. 915-926, 2014.

[49] L. Fan, Z. Zhang, Y. Yu, P. Li, and T. Cosgrove, "Effect of elevated curing temperature on ceramsite concrete performance," Construction and Building Materials, vol. 153, pp. 423-429, 2017.

[50] I. Elkhadiri and F. Puertas, "The effect of curing temperature on sulphate-resistant cement hydration and strength," Construction and Building Materials, vol. 22, no. 7, pp. 1331-1341, 2008.

[51] M. Neuenschwander, M. Knobloch, and M. Fontana, "Suitability of the damage-plasticity modelling concept for concrete at elevated temperatures: experimental validation with uniaxial cyclic compression tests," Cement and Concrete Research, vol. 79, pp. 57-75, 2016.

[52] Y. Wei, W. Guo, and S. Liang, "Microprestresssolidificationtheory-based tensile creep modeling of earlyage concrete: considering temperature and relative humidity effects," Construction and Building Materials, vol. 127, pp. 618-626, 2016.

[53] K. Wu and Z. Shao, "Visco-elastic analysis on the effect of flexible layer on mechanical behavior of tunnels," International Journal of Applied Mechanics, vol. 11, no. 3, article 1950027, 2019.

[54] J. B. Wang, W. W. Li, and Z. P. Song, "Development and implementation of new triangular finite element based on MGE theory for bi-material analysis," Results in Physics, vol. 13, article 102231, 2019.

[55] M. R. Son and N. Y. Kim, "Characteristics of adhesive strength and breaking plane at shotcrete-rock interface," Journal of Korean Society of Civil Engineers C, vol. 27, pp. 353-361, 2007.

[56] H. Mouzannar, M. Bost, M. Leroux, and D. Virely, "Experimental study of the shear strength of bonded concreterock interfaces: surface morphology and scale effect," Rock Mechanics and Rock Engineering, vol. 50, no. 10, pp. 26012625, 2017.

[57] X. Wang, J. Lai, and R. Garnes, "On the support system for tunnelling in squeezing ground of qingling-daba 
mountainous area: case study from soft rock tunnels," Advances in Civil Engineering, vol. 2019, Article ID 8682535, 12 pages, 2019.

[58] J. Lai, J. Qiu, H. Fan, Q. Zhang, J. Wang, and J. Chen, "Fiber bragg grating sensors-basedin-situ monitoring and safety assessment of loess tunnel," Journal of Sensors, vol. 2016, Article ID 8658290, 10 pages, 2016.

[59] J. Qiu, T. Yang, X. Wang, and G. Zhang, "Review of the flame retardancy on highway tunnel asphalt pavement," Construction and Building Materials, vol. 195, pp. 468-482, 2019.

[60] A. Krounis, F. Johansson, and S. Larsson, "Shear strength of partially bonded concrete-rock interfaces for application in dam stability analyses," Rock Mechanics and Rock Engineering, vol. 49, no. 7, pp. 2711-2722, 2016.

[61] A. Krounis, F. Johansson, and S. Larsson, "Effects of spatial variation in cohesion over the concrete-rock interface on dam sliding stability," Journal of Rock Mechanics and Geotechnical Engineering, vol. 7, no. 6, pp. 659-667, 2015.

[62] F. Fan, Z. Liu, G. Xu, H. Peng, and C. S. Cai, "Mechanical and thermal properties of fly ash based geopolymers," Construction and Building Materials, vol. 160, pp. 66-81, 2018.

[63] Z.-F. Wang, S.-L. Shen, and G. Modoni, "Enhancing discharge of spoil to mitigate disturbance induced by horizontal jet grouting in clayey soil: theoretical model and application," Computers and Geotechnics, vol. 111, pp. 222-228, 2019.

[64] G. C. Andreu, E. Miren, C. S. Poon et al., "Influence of steam curing on the pore structures and mechanical properties of fly-ash high performance concrete prepared with recycled aggregates," Cement and Concrete Composites, vol. 71, pp. 77-84, 2016.

[65] S. Cui, B. Zhu, F. Li, and Y. Ye, "Experimental study on bond performance between shotcrete and rock in a hot and humid tunnel environment," KSCE Journal of Civil Engineering, vol. 20, no. 4, pp. 1385-1391, 2016.

[66] S. Cui, P. Liu, J. Su, E. Cui, C. Guo, and B. Zhu, "Experimental study on mechanical and microstructural properties of cement-based paste for shotcrete use in high-temperature geothermal environment," Construction and Building Materials, vol. 174, pp. 603-612, 2018.

[67] H. Ozturk and D. D. Tannant, "Influence of rock properties and environmental conditions on thin spray-on liner adhesive bond," International Journal of Rock Mechanics and Mining Sciences, vol. 48, no. 7, pp. 1196-1198, 2011.

[68] M. E. Kuchta, "Quantifying the increase in adhesion strength of shotcrete applied to surfaces treated with high-pressure water," Transactions of Society for Mining, Metallurgy, and Exploration, Inc, vol. 312, pp. 129-132, 2002.

[69] D. Saiang, L. Malmgren, and E. Nordlund, "Laboratory tests on shotcrete-rock joints in direct shear, tension and compression," Rock Mechanics and Rock Engineering, vol. 38, no. 4, pp. 275-297, 2005.

[70] R. Qiao, Z. Shao, W. Wei, and Y. Zhang, "Theoretical investigation into the thermo-mechanical behaviours of tunnel lining during RABT fire development," Arabian Journal for Science and Engineering, vol. 44, no. 5, pp. 4807-4818, 2019.

[71] P. Bamonte and P. G. Gambarova, "A study on the mechanical properties of self-compacting concrete at high temperature and after cooling," Materials and Structures, vol. 45, no. 9, pp. 1375-1387, 2012.

[72] A. Ansell, "Shotcrete on rock exposed to large-scale blasting," Magazine of Concrete Research, vol. 59, no. 9, pp. 663-671, 2007.
[73] L. Luo, X. Li, M. Tao, and L. Dong, "Mechanical behavior of rock-shotcrete interface under static and dynamic tensile loads," Tunnelling and Underground Space Technology, vol. 65, pp. 215-224, 2017.

[74] Z. J. Zhou, S. S. Zhu, X. Kong, J. T. Lei, and T. Liu, “Optimization analysis of settlement parameters for postgrouting piles in loess area of Shaanxi, China," Advances in Civil Engineering, vol. 2019, Article ID 7085104, 16 pages, 2019.

[75] I. Galan, A. Baldermann, W. Kusterle, M. Dietzel, and F. Mittermayr, "Durability of shotcrete for underground support-review and update," Construction and Building Materials, vol. 202, pp. 465-493, 2019.

[76] P. Bamonte and R. Felicetti, "High-temperature behaviour of concrete in tension," Structural Engineering International, vol. 22, no. 4, pp. 493-499, 2012.

[77] L. Duan, W. Lin, J. Lai, and P. Zhang, "Vibration characteristic of high-voltage tower influenced by adjacent tunnel blasting construction," Shock and Vibration, vol. 2019, Article ID 8520564, 16 pages, 2019.

[78] Z. Zhou, Y. Dong, P. Jiang, D. Han, and T. Liu, "Calculation of pile side friction by multiparameter statistical analysis," Advances in Civil Engineering, vol. 2019, Article ID 2638520, 12 pages, 2019.

[79] Z. J. Zhou, J. T. Lei, S. B. Shi, and T. Liu, "Seismic response of aeolian sand high embankment slopes in shaking table tests," Applied Sciences, vol. 9, no. 8, p. 1677, 2019.

[80] X. B. Yue, Y. L. Xie, H. G. Zhang, and Y. P. Niu, "Study on geotechnical characteristics of marine soil at HongkongZhuhai-Macao tunnel," Marine Georesources and Geotechnology, vol. 37, no. 3, 2019.

[81] Y. Jiang, X. Zhang, and T. Taniguchi, "Quantitative condition inspection and assessment of tunnel lining," Automation in Construction, vol. 102, pp. 258-269, 2019.

[82] G. Q. Bai, W. G. Qiu, and J. R. Zhang, "Research on thermal insulation technology of high ground temperature tunnel," Railway Standard Design, vol. 2, pp. 77-80, 2013, in Chinese.

[83] G. Promis, A. Gabor, G. Maddaluno, and P. Hamelin, "Behaviour of beams made in textile reinforced mineral matrix composites, an experimental study," Composite Structures, vol. 92, no. 10, pp. 2565-2572, 2010.

[84] V. Afroughsabet, L. Biolzi, and T. Ozbakkaloglu, "Influence of double hooked-end steel fibers and slag on mechanical and durability properties of high performance recycled aggregate concrete," Composite Structures, vol. 181, pp. 273-284, 2017.

[85] X. L. Luo, X. Meng, W. J. Gan, and Y. H. Chen, "Traffic data imputation algorithm based on improved low rank matrix decomposition," Journal of Sensors, vol. 2019, Article ID 7092713, 10 pages, 2019.

[86] D. Pedro, J. de Brito, and L. Evangelista, "Mechanical characterization of high performance concrete prepared with recycled aggregates and silica fume from precast industry," Journal of Cleaner Production, vol. 164, pp. 939-949, 2017.

[87] Y.-H. Kwon, S.-H. Kang, S.-G. Hong, and J. Moon, "Acceleration of intended pozzolanic reaction under initial thermal treatment for developing cementless fly ash based mortar," Materials, vol. 10, no. 3, p. 225, 2017.

[88] A. Akhtar and A. K. Sarmah, "Construction and demolition waste generation and properties of recycled aggregate concrete: a global perspective," Journal of Cleaner Production, vol. 186, pp. 262-281, 2018.

[89] D. Wang, Q. Wang, and Z. Fang, "Influence of alkali activators on the early hydration of cement-based binders under 
steam curing condition," Journal of Thermal Analysis and Calorimetry, vol. 130, no. 3, pp. 1801-1816, 2017.

[90] K. P. Verian, W. Ashraf, and Y. Cao, "Properties of recycled concrete aggregate and their influence in new concrete production," Resources, Conservation and Recycling, vol. 133, pp. 30-49, 2018.

[91] Y. Y. Li, W. S. Lin, Y. W. Zhang, and K. Wang, "Vibration characteristics and damage repair of the railway tunnel base," Advances in Civil Engineering, vol. 2019, Article ID 1097203, 16 pages, 2019.

[92] Y. Kim, A. Hanif, M. Usman, M. J. Munir, S. M. S. Kazmi, and S. Kim, "Slag waste incorporation in high early strength concrete as cement replacement: environmental impact and influence on hydration \& durability attributes," Journal of Cleaner Production, vol. 172, pp. 3056-3065, 2018.

[93] S. Abdallah, D. W. A. Rees, S. H. Ghaffar, and M. Fan, "Understanding the effectss of hooked-end steel fibre geometry on the uniaxial tensile behaviour of self-compacting concrete," Construction and Building Materials, vol. 178, pp. 484-494, 2018.

[94] S.-J. Lee, D.-Y. Yoo, and D.-Y. Moon, "Effects of hooked-end steel fiber geometry and volume fraction on the flexural behavior of concrete pedestrian decks," Applied Sciences, vol. 9, no. 6, p. 1241, 2019.

[95] J. Pei, B. Zhou, and L. Lyu, "e-Road: the largest energy supply of the future?," Applied Energy, vol. 241, pp. 174-183, 2019.

[96] G. L. Golewski, "An assessment of microcracks in the interfacial transition zone of durable concrete composites with fly ash additives," Composite Structures, vol. 200, pp. 515520, 2018.

[97] Y. C. Zheng, H. Zhong, Y. Fang, W. S. zhang, K. Liu, and J. Fang, "Rockburst prediction model based on entropy weight integrated with grey relational -BP neural network," Advances in Civil Engineering, vol. 2019, Article ID 3453614, 8 pages.

[98] K. M. Liew, A. O. Sojobi, and L. W. Zhang, "Green concrete: prospects and challenges," Construction and Building Materials, vol. 156, pp. 1063-1069, 2017.

[99] P. Li, F. Wang, L. Fan, H. Wang, and G. Ma, "Analytical scrutiny of loosening pressure on deep twin-tunnels in rock formations," Tunnelling and Underground Space Technology, vol. 83, pp. 373-380, 2019.

[100] X. Liu, Q. Fang, D. L. Zhang, and Z. J. Wang, "Behaviour of existing tunnel due to new tunnel construction below," Computers and Geotechnics, vol. 110, pp. 71-81, 2019.

[101] W. Cheng, J. Ni, A. Arulrajah, and H. Huang, "A simple approach for characterising tunnel bore conditions based upon pipe jacking data," Tunnelling and Underground Space Technology, vol. 71, pp. 494-504, 2018.

[102] Y. Zheng, J. Xiong, T. Liu, X. Yue, and J. Qiu, "Performance of a deep excavation in Lanzhou strong permeable sandy gravel strata," Arabian Journal of Geosciences, vol. 12, no. 16, p. 12, 2019.

[103] D. M. Zhang, Z. K. Huang, Z. L. Li, X. Zong, and D. M. Zhang, "Analytical solution for the response of an existing tunnel to a new tunnel excavation underneath," Computers and Geotechnics, vol. 108, pp. 197-211, 2019. 


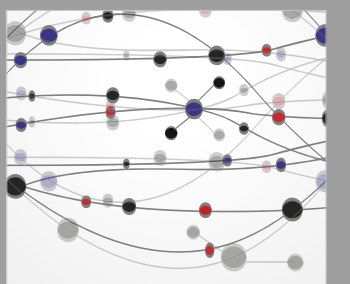

The Scientific World Journal
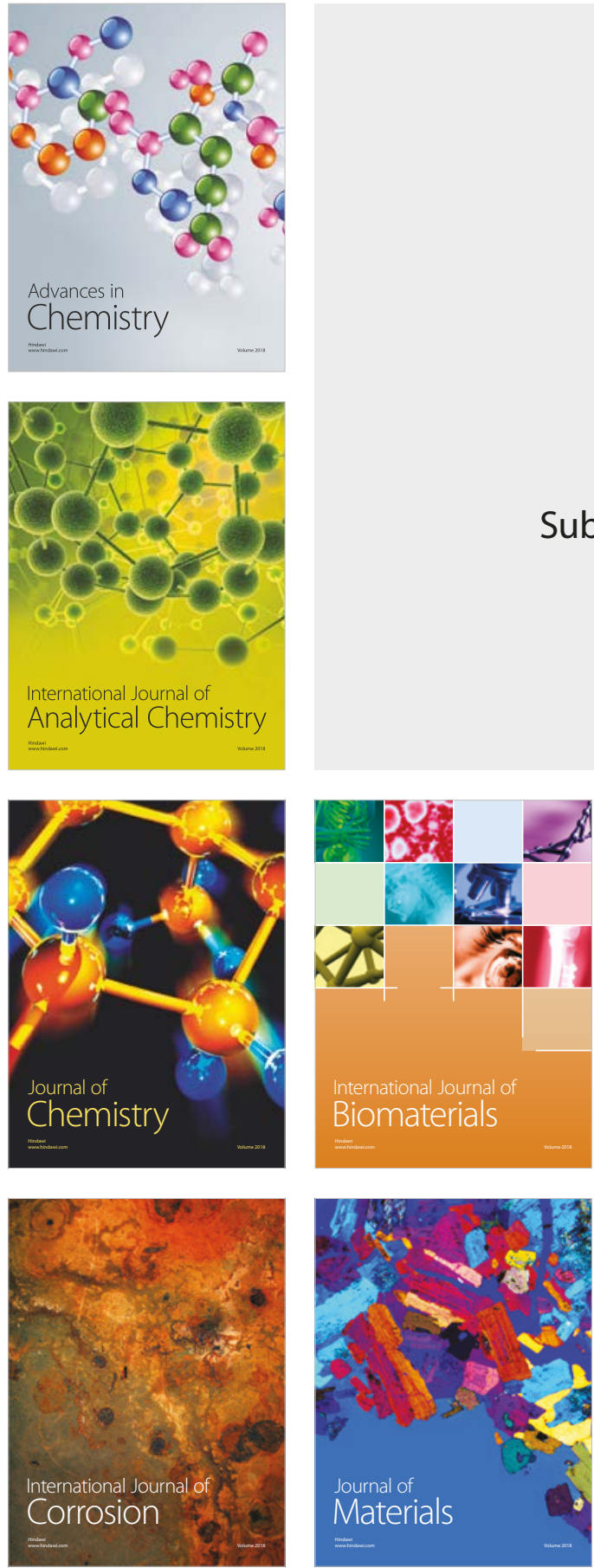

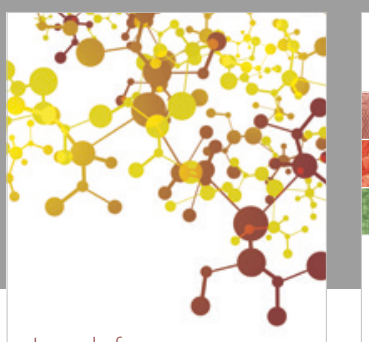

Journal of

Applied Chemistry
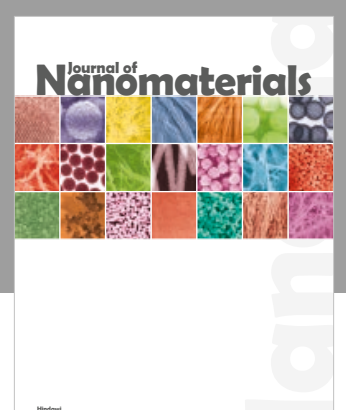

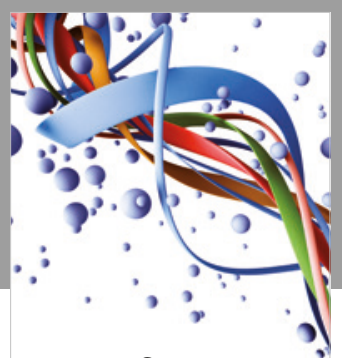

Scientifica

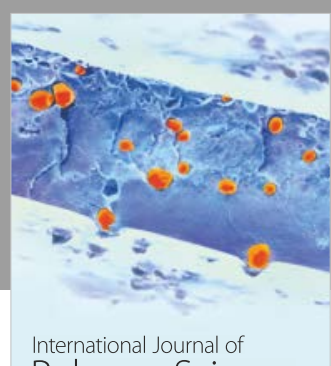

Polymer Science

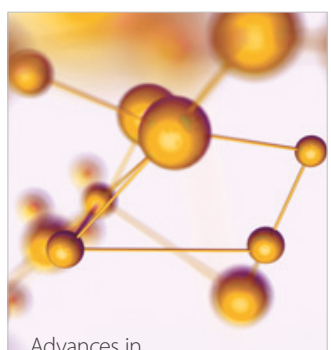

Physical Chemistry
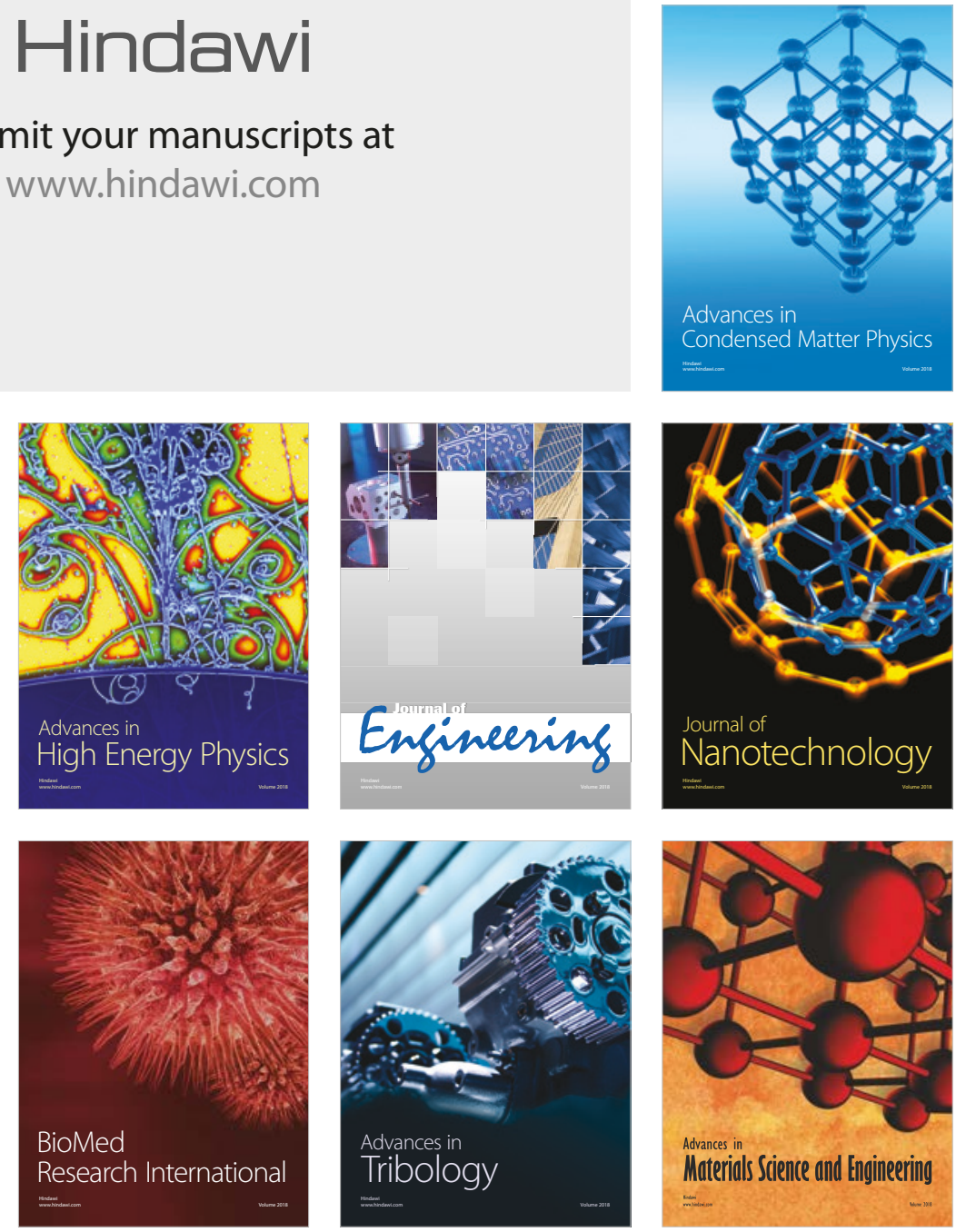